\title{
Impact of long-term benthic trawl disturbance on sediment sorting and biogeochemistry in the southern North Sea
}

\author{
M. Trimmer ${ }^{1, *}$, J. Petersen ${ }^{1}$, D. B. Sivyer ${ }^{2}$, C. Mills ${ }^{2}$, E. Young², E. R. Parker ${ }^{2}$ \\ ${ }^{1}$ School of Biological Sciences, Queen Mary, University of London, London E1 4NS, UK \\ ${ }^{2}$ Centre for Environment Fisheries and Aquaculture Sciences, Lowestoft NR33 0HT, UK
}

\begin{abstract}
Benthic trawling has a recognised impact on sediment whole organism communities, yet little is known about its impact on sediment biogeochemistry. On 2 cruises in October 2001 and July 2002, we measured sediment characteristics (particle size distribution, porosity and organic matter [OM]) and sediment metabolism (oxygen uptake, denitrification, sulphate reduction and sedimentwater nutrient exchange) along gradients of trawling activity at 14 sites in 2 regions of the southern North Sea: one with low tidal disturbance but high trawling disturbance (Outer Silver Pit, OSP), the other with high tidal disturbance but lower trawling disturbance (Thames). There was no measurable impact of trawling activity on oxygen uptake, denitrification or nutrient exchange in either region. In contrast, at the high trawling disturbance sites in the OSP only, there was both a shift in particle size distribution (towards fines) and a greater rate of sulphate reduction (volume specific rates 0.83 and $0.49 \mathrm{nmol} \mathrm{SO}{ }_{4}{ }^{2-} \mathrm{cm}^{-3} \mathrm{~h}^{-1}$ at high and low impact sites, respectively), but not in the Thames. In addition, areal rates of sulphate reduction were positively correlated with both silt content (i.e. associated with organics) and long-term trawling in the OSP but not in the Thames. Biogeochemical processes in the upper layers of sediment, both oxic and suboxic, seemed unaffected by trawling in the longterm. In deeper anoxic sediment, however, mineralisation via sulphate reduction may be stimulated by the extra disturbance, at least in areas where tidal energy is slight.
\end{abstract}

KEY WORDS: Impact · Trawling $\cdot$ Disturbance $\cdot$ Biogeochemistry $\cdot$ Sulphate reduction $\cdot$ Sediments

\section{INTRODUCTION}

The total trawling effort in the North Sea has increased since the late 1970 s to about 2.64 million fishing hours $\mathrm{yr}^{-1}$ in 1998, of which $37 \%$ is beam trawling (Jennings et al. 1999, Callaway et al. 2002). On average, every square metre of bed is trawled at least 7 times a year (Rijnsdorp et al. 1998). Fishing effort is also very patchy, with a few ICES rectangles (3500 $\mathrm{km}^{2}$ ) subjected to very intensive disturbance indeed (4\% exceeded $40000 \mathrm{~h}$ of fishing $\mathrm{yr}^{-1}, 66 \%$ received less than $10000 \mathrm{~h}$ ). The distribution of effort is also very patchy at smaller scales. For example, analysis of fishing impacts by the Dutch beam trawl fleet (using 'black box' recorders) has shown that some areas (each $31 \mathrm{~km}^{2}$ ) are visited over 400 times $\mathrm{yr}^{-1}$, while others are never fished (Rijnsdorp et al. 1998). Globally, it has been estimated that trawling is responsible for the most intensive of all benthic disturbances and that an area equivalent to the total oceanic continental shelf is trawled every 2 yr (Watling \& Norse 1998).

Many studies have addressed the impact of trawling on the benthic macrofauna (both infauna and epifauna), and these communities are indeed heavily affected (De Groot \& Lindeboom 1994, Jennings \& Kaiser 1998, Kaiser \& De Groot 2000), while the smallbodied infauna is less vulnerable (Jennings et al. 2002). There has been far less attention paid to the potential effects of trawling on biogeochemical processes in the sediment (Watling et al. 2001). This is anomalous given our extensive understanding of the effect of natural bioturbation by benthic animals on 
biogeochemical cycles (Henriksen et al. 1983, Aller 1988, Kristensen 2000). Continental shelf sediments are significant in the global biogeochemical cycling of carbon $(\mathrm{C})$ and nitrogen $(\mathrm{N})$. Although shelf sediments make up only $9 \%$ of the total oceanic sediment area, they are responsible for about $83 \%$ of all oceanic benthic mineralisation (Jørgensen 1983), so any effect of trawling on biogeochemical cycling could be important.

Benthic trawling resuspends surface sediments (Churchill 1989, Riemann \& Hoffmann 1991, Pilskaln et al. 1998, Palanques et al. 2001), which can result in an immediate release of nutrients into the overlying water column, although data are sparse (Fanning et al. 1982, Krost 1990, Falcão et al. 2003). Blackburn (1997) calculated the release of $\mathrm{N}$ compounds following resuspension of sediment for a variety of scenarios (rate of OM decomposition and distribution with depth) and concluded that 0.8 to $2.4 \mathrm{~cm}$ of sediment would need to be resuspended to liberate $5 \mathrm{mmol} \mathrm{N} \mathrm{m}^{-2}$ into the overlying water column and, as trawling gears often penetrate beyond this depth, such release seems likely (Lindeboom \& de Groot 1998). Previous measurements of ammonium release from trawled sediment have not always been conclusive, however (Riemann \& Hoffmann 1991, Warnken et al. 2003). Despite these uncertainties the potential magnitude of such nutrient pulses, relative to a diffusional efflux, is substantial (Pilskaln et al. 1998, Krost 1990, Falcão et al. 2003). Critically, Falcão et al. (2003) observed that, although clam dredging altered the structure of pore water nutrient profiles and generated an immediate nutrient pulse, pre-dredge concentrations were quickly restored (i.e. within minutes to hours) in both the sediment pore-water and overlying water, as predicted by Blackburn (1997).

Benthic trawling can alter the organic structure of sediments through a combination of the removal of surficial sediments and the turnover and burial of OM (Mayer et al. 1991, Watling et al. 2001). Such a redistribution of OM could potentially shift the balance between aerobic and anaerobic mineralisation simply because it is buried beneath the narrow oxic zone before mineralisation is complete (Berner 1985, Mayer et al. 1991, Pilskaln et al. 1998). Locally, oxygen can decrease in the overlying water immediately after trawling, as reduced substrata are mixed into the water column, and there is some evidence to suggest that trawling affects the actual rate of benthic sediment oxygen uptake (Riemann \& Hoffmann 1991, Warnken et al. 2003). Together, these disturbances to the oxygen regime could influence key steps in the $\mathrm{N}$ cycle, as oxygen regulates both nitrification and denitrification in benthic sediments (Rysgaard et al. 1994). Indirectly, trawling may affect the oxygen regime and biogeochemical processing by altering the composition of the benthic fauna, which itself regulates oxygen and redox structure through bioturbation and bio-irrigation (Henriksen et al. 1983, Aller 1988, Pelegri et al. 1994, Kristensen 2000).

Previous studies on immediate nutrient release and oxygen consumption in impacted sediments have been small-scale and short-term. Moreover, no single study has simultaneously measured key components of sedimentary biogeochemistry, namely oxygen, sulphate and nitrate respiration, along a gradient of long-term trawling activity. Our purpose here was to focus on the long-term impacts of benthic trawling on sediment characteristics and biogeochemical processes in 2 regions of the North Sea.

\section{MATERIALS AND METHODS}

Sampling site selection. Measurements were made on 2 cruises by the RV 'Corystes', in October 2001 and July 2002. Sediment characteristics and sediment metabolism were measured along gradients of benthic trawling activity in 2 regions of the southern North Sea (Fig. 1), one with low tidal disturbance but high overall trawling disturbance (Outer Silver Pit, OSP, International Council for the Exploration of the Sea [ICES] Area IVb), the other with high tidal disturbance but low overall trawling disturbance (Thames, ICES Area VIIc). The Thames water column is known to be well mixed throughout the year, and this was observed on both cruises (e.g. $16^{\circ} \mathrm{C}$ over $36 \mathrm{~m}$ ). The OSP was well mixed in the October cruise (e.g. 13.3 to $13.4^{\circ} \mathrm{C}$ over $71 \mathrm{~m}$ ) but strong stratification (mainly thermal) was observed in July (e.g. $16^{\circ} \mathrm{C}$ surface to $11.2^{\circ} \mathrm{C}$ at $73 \mathrm{~m}$ ). Within these 2 regions, which differed in overall trawling intensity, sites subjected to differing local intensity trawling were selected (see Table 1, and next subsection for calculation of impact). Site selection was based on existing knowledge of sediment type, water depth and natural tidal bed-stresses to ensure comparability. Within each region sites were selected along a gradient of trawling intensity estimated using a combination of historical overflight and satellite positioning information of fleets (see next subsection) in a GIS (Geographical Information System, in this case, ArcView Spatial Analyst $8^{\circledR}$ ). The initial sites (4 in each region) were selected using overflight data from 1999 to 2001 and satellite (European Community Satellite Vessel Monitoring System, VMS) data from January to September 2001. Additional sites were added in 2002 using this approach and more up to date satellite data (see Table 1).

Trawling intensity: overflight historical data. Overflight data have been collected by the British Fishery Protection flights, the Royal Navy and Fishery Protec- 


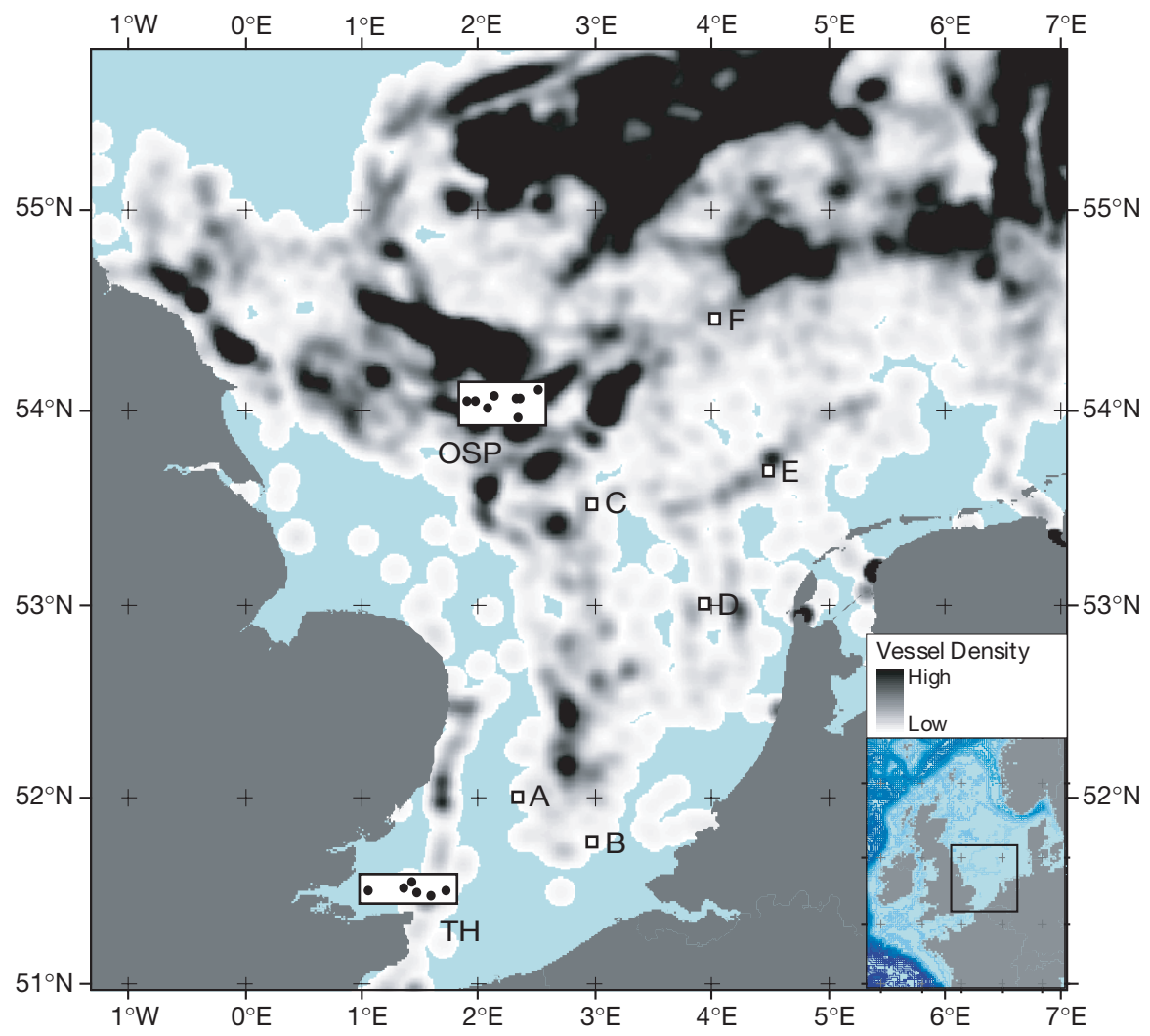

Fig. 1. Sampling sites in present study (TH: Thames; OSP: Outer Silver Pit) and other sites in the southern North Sea where biogeochemical processes have been previously measured. A: Site 12 of Trimmer et al. (2000); B: Site 1 of Upton et al (1993); C: Site 6 of Upton et al. (1993); D: Broad Fourteens site of van Raaphorst et al. (1992) and Osinga et al. (1996); E: Frisian Front site of van Raaphorst et al. (1992); F: Oyster Grounds site of Lohse et al. (1996) and Osinga et al. (1996). Density (vessels $\mathrm{km}^{-2}$ ) of benthic trawlers operating in a portion of the southern North Sea in 2002 is also shown

tion vessels during patrols of the central and southern North Sea since 1985, and can therefore be used to provide a long-term overview of the distributions of trawling in ICES subrectangles (4 areas of $0.25^{\circ}$ latitude $\times 0.5^{\circ}$ longitude within each ICES rectangle) . Overflight data were used to derive an historical standardised index of fishing intensity, measured as sightings per unit effort (SPUE) for the period 1990 to 2002, i.e. the annual total number of actively fishing vessels recorded in each sub-subrectangle $\left(0.125^{\circ}\right.$ latitude $\times$ $0.25^{\circ}$ longitude) divided by the number of visits to the associated subrectangle.

Trawling intensity: satellite information. Since 2000 European Community vessels over $24 \mathrm{~m}$ long have reported their position by satellite every $2 \mathrm{~h}$. This high frequency data allows the fine scale spatial and temporal distribution of trawling to be examined. The frequency of beam trawling disturbance (vessel numbers $\mathrm{km}^{-2}$ ) in the study areas was calculated within a GIS. This density approach works by summing the number of points within a search radius for a given area $\left(\mathrm{km}^{2}\right)$ and dividing the result by the area. The search radius was determined using an ad hoc approach (Silverman 1986), which calculated a most suitable radius of approximately $9 \mathrm{~km}$ and produced a surface that best describes local variation in fishing intensity with minimal over-smoothing.

European Community Satellite Vessel Monitoring System (VMS) data are not collected for the purpose of estimating trawling intensity, and therefore several assumptions and caveats apply. Some beam trawler positions may have been excluded from the initial querying of the VMS database, due to the vessels having no gear type classification. Vessel speed was used as a filter according to gear type (3 to 8 knots for beams, 1 to 4 knots for otters/shellfish dredgers and pair trawlers). Only vessels over $24 \mathrm{~m}$ in length were recorded, so VMS trawling intensity estimates would exclude most inshore effort by small vessels. This is especially relevant for the Thames, although the inshore effort there should be captured by overflight information. Despite these limitations, the VMS data provide the best available estimate of the small-scale spatial distribution of fishing activity.

Bed-stress model data. A 3-dimensional tide-, windand density-driven hydrodynamic model of the North Sea, based on the Princeton Ocean Model, POM (Blumberg \& Mellor 1987, E. F. Young unpubl.), was used to predict M2 (diurnal lunar contribution) tidal currents, at a spatial resolution of $1 / 20$ longitude $\times$ 1/30 latitude (approx. $3.5 \mathrm{~km}$ ). Bed-stresses due to the M2 tide (i.e. mean with no spring/neap peaks) were then calculated with stress $\left(\mathrm{N} \mathrm{m}^{-2}\right)$ dependent on the predicted maximum ellipse current and an assumed bed friction coefficient of 0.0025 .

Sediment collection and storage. Once a potential site had been defined, the research vessel was held within a $100 \mathrm{~m}$ radius 'bull-ring' within which all sediment and water samples were collected. Between surveys in October 2001 and July 2002, Site OSP1 was disturbed by pipe-laying and the site was moved due west to an area with comparable intensity and background characteristics and renamed OSP1b. Sediment and overlying water samples were first brought on board ship using a NIOZ (Netherlands Institute for Sea 
Research, Texel) cylindrical box corer $(31 \mathrm{~cm}$ inner diameter, i.d., Netherlands Institute for Sea Research). To determine a biogeochemical rate or sediment characteristic at any one site (e.g. OSP1) within a region (OSP or Thames) multiple sub-cores were collected from a series of box core deployments. The 3 subcores, to measure oxygen uptake, for example, would not necessarily come from the same box core, but were allocated at random amongst the box cores as they came on deck and a total of 8 to 12 box cores would be sampled at any one site. The box corer collected 30 to $50 \mathrm{~cm}$ of sediment and 15 to $25 \mathrm{l}$ of site water. Box cores that had drained were discarded and the box corer redeployed. To measure benthic oxygen uptake, sulphate reduction and nutrient exchange, 12 large sediment sub-cores (30 cm deep) and overlying water (1 l) were collected in triplicate at each site using Perspex tubes $(65 \mathrm{~cm}$ long $\times 8 \mathrm{~cm}$ i.d.), each sealed at the bottom with a silicone rubber bung. Smaller sediment sub-cores ( 10 cm deep) and overlying water $(\sim 100 \mathrm{ml})$ to measure benthic denitrification were collected from the box corer using Perspex tubes $(20 \mathrm{~cm}$ long $\times 3.4 \mathrm{~cm}$ i.d.). The sub-cores collected to measure oxygen uptake, sulphate reduction and denitrification were immersed open in aerated water baths containing collected bottom site water and allowed to re-equilibrate for $2 \mathrm{~h}$ at in situ temperature. The sediment-water nutrient exchange cores were topped up with site water $(750 \mathrm{ml})$, capped, and supplied with gentle aeration (for mixing and to prevent oxygen depletion) and placed in a thermostatically controlled water bath at in situ temperature. To determine various characteristics (porosity, particle size, OM, 4 additional sediment cores $(30 \mathrm{~cm} \times 6 \mathrm{~cm}$ i.d.) were also collected and processed immediately.

Sediment characteristics. Sediment porosity, particle size and $\mathrm{OM}$ were measured at $1 \mathrm{~cm}$ depth intervals on extruded samples down to $10 \mathrm{~cm}$. Porosity was calculated using the dry weights and wet weights of known volumes of sediment and assuming a sediment particle density of $2.7 \mathrm{~g} \mathrm{~cm}^{-3}$ and a seawater density of $1.035 \mathrm{~g} \mathrm{~cm}^{-3}$. Particle size was measured by laserdiffraction using a Malvern Mastersizer 2000 which gives an absolute measure for each size class (Malvern Instruments). Dispersed sediment samples are suspended in a volume of rapidly circulating water which ensures random distribution during laser measurement. Data were expressed on the Wentworth scale in $\mu \mathrm{m}$ rather than $\mathrm{mm}$. Organic matter content was crudely estimated by loss on ignition at $550^{\circ} \mathrm{C}$ after acidification to remove carbonates.

Rate process measurements. Oxygen uptake: Oxygen uptake was measured using 3 of the large cores, which were capped and completely water-filled to exclude air bubbles. The water column in each tube was then stirred with an induction motor driving a magnetic follower (Rank Brothers) at $300 \mathrm{rpm}$. A midcolumn water sample $(20 \mathrm{ml})$ was then drawn off into a gas tight syringe and gently transferred to a gas tight vial (Exetainer, $12 \mathrm{ml}$, Labco) and fixed for Winkler analysis of dissolved oxygen for electrode calibration. The rates of sediment $\mathrm{O}_{2}$ uptake were measured using Clark-type $\mathrm{O}_{2}$ electrodes coupled to a 6 channel $\mathrm{O}_{2}$ meter and data analysis software (Strathkelvin), which enabled the $\mathrm{O}_{2}$ concentration in the water column to be continuously monitored and statistically analysed for linearity with respect to time.

Sediment-water nutrient exchange: Water samples $(20 \mathrm{ml})$ were taken every 2 to $4 \mathrm{~h}$ for $24 \mathrm{~h}$ from each sediment-water nutrient exchange core through a sample port, filtered (0.2 $\mu \mathrm{m}$ Minisart Plus ${ }^{\mathrm{TM}}$, Sartorius) and frozen at $-20^{\circ} \mathrm{C}$ prior to analyses. Triplicate water samples $(750 \mathrm{ml})$ with no sediment present acted as controls for water column processes in the absence of sediment-water exchange. All the water samples were later analysed for $\mathrm{NO}_{3}{ }^{-}$and $\mathrm{SiO}_{3}{ }^{2-}$ ( $\mathrm{Si}$ ) using a segmented flow autoanalyser (Skalar) and standard techniques (Kirkwood 1996). Ammonium exchange data were unfortunately unreliable due to contamination from the filters and were discarded. Nutrient concentrations were plotted against time, and exchange rates were calculated from linear regression and converted to $\mu \mathrm{mol} \mathrm{m}{ }^{-2} \mathrm{~h}^{-1}$ using the overlying water volume and sediment surface area accordingly.

Sulphate reduction: Rates of sulphate reduction were measured using an adapted $\left[{ }^{35} \mathrm{~S}\right] \mathrm{SO}_{4}{ }^{2-}$ radiotracer technique (Sorokin 1962) at 5 depths at each site down to a maximum of $20 \mathrm{~cm}$, depending on sediment type. Each of the final 3 large cores were extruded, and horizontal mini-cores of sediment were collected at $1 \mathrm{~cm}$ horizons using truncated hypodermic syringes $(5 \mathrm{ml})$, and sealed with Suba-seals. The use of discrete sealed mini-cores prevents the possible reoxidation of ${ }^{35} \mathrm{~S}$ to ${ }^{35} \mathrm{SO}_{4}{ }^{2-}$ in the oxic layer of an intact core. To minimise air exposure the sediment above each sampled depth horizon was left in place, thus only the sediment face $\left(0.78 \mathrm{~cm}^{2}\right)$ was exposed. Each mini-core was injected along its length through the Suba-seal with $100 \mu \mathrm{l}$ of sodium $\left[{ }^{35} \mathrm{~S}\right]$ sulphate solution $(185 \mathrm{kBq}$ [5 $\mu \mathrm{Ci}$ ], specific activity $1.24 \mathrm{GBq} . \mathrm{mmol}^{-1}$; Amersham) and incubated at the in situ temperature for 16 to $24 \mathrm{~h}$. At the end of the incubation the sediment from each mini-core was placed into a pot containing zinc acetate solution $(20 \mathrm{ml}$ of $5 \% \mathrm{w} / \mathrm{v})$, mixed and frozen at $-20^{\circ} \mathrm{C}$.

After thawing, the entire fixed samples of sediment were digested to recover both acid volatile sulphides (AVS) and tin-reducible sulphides (TRS), which include pyrite (Nedwell \& Takii 1988). The hydrogen sulphide evolved from the digested samples was collected in 2 serial zinc acetate traps $(40 \mathrm{ml}, 1 \% \mathrm{w} / \mathrm{v})$. The 
slurry remaining after digestion of each sediment sample was centrifuged, decanted, and made up to a known volume $(250 \mathrm{ml})$. Duplicate subsamples from the zinc acetate traps $(2 \mathrm{ml})$ and the residual sediment digests $(0.1 \mathrm{ml}+0.9 \mathrm{ml}$ ultra high purity water) were added to scintillation fluid (3 ml Hydrofluor, National Diagnostics) and the radioactivity counted in a scintillation counter (Rackbeta). Pore water was extracted under vacuum at each respective depth from box cores, and sulphate concentrations were measured by ion exchange chromatography (Series 2000 i, Dionex). The turnover of ${ }^{35}$ sulphate to ${ }^{35}$ sulphide was used to calculate the rate of sulphate reduction, according to Fossing \& Jørgensen (1989), using the measured porosity and sulphate concentration at each respective depth.

Denitrification: To measure denitrification, we used 6 small sediment cores and the ${ }^{15} \mathrm{NO}_{3}{ }^{-}$isotope pairing technique of Nielsen (1992), as described by Trimmer et al. (2000). Of the 6 cores, 4 were spiked (treatments) to give a final concentration of approximately $50 \mu \mathrm{M}$, i.e. $>98 \%{ }^{15} \mathrm{NO}_{3}{ }^{-}$(atom\%) by addition of $\mathrm{Na}^{15} \mathrm{NO}_{3}{ }^{-}$ $(50 \mu \mathrm{l})$ from a concentrated stock $\left(100 \mathrm{mM} \mathrm{Na}{ }^{15} \mathrm{NO}_{3}{ }^{-}\right.$ [99.3 atom\%, Europa Instruments]) into the overlying water, and left to equilibrate for $0.5 \mathrm{~h}$ (Rysgaard et al. 1995); 2 unamended cores were used as references. Water samples $(2 \mathrm{ml})$ collected from all core tubes to determine the initial ${ }^{14} \mathrm{NO}_{3}{ }^{-}:{ }^{15} \mathrm{NO}_{3}{ }^{-}$ratio in the water overlying the treatment cores were filtered and preserved prior to analyses (see 8th subsection above). The sediment in the 2 reference cores was then gently mixed into a slurry with the overlying water and a sample $(20 \mathrm{ml})$ was carefully drawn off into a gas-tight vial (Exetainer, $12 \mathrm{ml}$, Labco) containing $\mathrm{ZnCl}_{2}$ solution (500 $\mu \mathrm{l}, 25 \% \mathrm{w} / \mathrm{v})$ and sealed. The ${ }^{15} \mathrm{NO}_{3}{ }^{-}$enriched cores were sealed and incubated in the dark at the in situ temperature, with gentle stirring ( $60 \mathrm{rpm})$ of the water column for 2 to $6 \mathrm{~h}$. The onscreen data logging in the parallel oxygen uptake cores ensured that the concentration of oxygen in the overlying water never fell below $80 \%$ of air-saturation (see 'oxygen uptake' above). Following incubation, the ${ }^{15} \mathrm{NO}_{3}{ }^{-}$enriched cores were processed as for the reference cores.

All the slurry samples were sent to the National Environmental Research Institute, Silkeborg, Denmark, to be analysed for abundance and concentration of ${ }^{28} \mathrm{~N}_{2},{ }^{29} \mathrm{~N}_{2}$ and ${ }^{30} \mathrm{~N}_{2}$ on a gas chromatograph coupled to a dual inlet isotope ratio mass spectrometer (Europa Instruments). Denitrification rates were calculated according to Nielsen (1992).

Anaerobic ammonium oxidation: Recently it has been shown that denitrification is not the only pathway for $\mathrm{N}_{2}$ formation in both shelf sea and estuarine sediments (Thamdrup \& Dalsgaard 2002, Trimmer et al. 2003b). Indeed, Thamdrup \& Dalsgaard (2002) measured between 24 and $60 \%$ of $\mathrm{N}_{2}$ formation via anaerobic ammonium oxidation in sediment from relatively deep water (380 and $695 \mathrm{~m}$, respectively). Clearly this alters our understanding of sedimentary $\mathrm{N}$ cycles, but it also has implications for the isotope pairing technique commonly employed to measure denitrification (Nielsen 1992, Risgaard-Petersen et al. 2003). Simply, the assumption that denitrification is the only source of ${ }^{29} \mathrm{~N}_{2}$ formation in the isotope pairing assay is no longer sound because ${ }^{29} \mathrm{~N}_{2}$ can also be formed via anaerobic ammonium oxidation. Although we did not characterise fully anaerobic ammonium oxidation at all sites we did quantify its potential contribution to $\mathrm{N}_{2}$ formation at 1 site in both regions using ${ }^{15} \mathrm{NO}_{3}{ }^{-}$and anaerobic sediment slurries, as described in Trimmer et al. (2003b).

Data analysis. All statistical analyses were performed using SPSS version 12. Accuracy of a process measurement at any one site was calculated as the standard error of a triplicate (or greater) measurement. Differences between mean rates either across sites within a region or between regions were analysed using 1-way ANOVA and post hoc analysis (Tukey's test). Homogeneity of variance and normality were tested using Levene's and Kolmogorov-Smirnov's tests, respectively. The data were first analysed using ANCOVA to test for any effect of date. The effect of 'trawling impact' over 'natural' sediment characteristics (e.g. silt content which is a proxy for OM content) was assessed within each region (OSP, Thames) using multiple linear regression. With sulphate reduction, for example, as the dependent variable and silt (\%) and then trawling intensity as independent variables. Depth profiles for sulphate reduction were averaged for sites grouped either by high or low intensity, which was assigned as either greater or less than the median value for impact intensity, respectively, in each region (see 'Results').

\section{RESULTS}

\section{Trawling impact intensities}

Trawling activity estimated from satellite (short-term 2001 and 2002) and overflight (long-term 1992 to 2002) data in the 2 regions is given in Table 1. In the OSP, for example, across 'high impact' and 'low impact' sites, long-term trawling ranged from 0.16 to 0.53 SPUE and in the Thames 0.06 to 0.29 SPUE. The pattern of trawling varied also across the years (Table 1, Fig. 2A) in each region. In the OSP, for example, the 2001 satellite data correlated well $(r=0.853, p=0.007)$ with the longterm data, whilst the satellite 2002 data did not. In contrast, in the Thames, the satellite 2001 data were not significantly correlated with the long-term trend but the 2002 data were $(r=0.817, p=0.047)$. 
Table 1. Position of sampling sites in each region of the southern North Sea, dates visited (+), original impact classification at time of first cruise (based on available historical data), and short-term satellite (vessel density $\mathrm{km}^{-2}$ ) and long-term overflight (sightings per unit effort) impact data. OSP: Outer Silver Pit; TH: Thames

\begin{tabular}{|c|c|c|c|c|c|c|c|}
\hline \multirow[t]{2}{*}{ Site } & \multirow[t]{2}{*}{ Position } & \multirow{2}{*}{$\begin{array}{c}\text { October } \\
2001\end{array}$} & \multirow{2}{*}{$\begin{array}{l}\text { July } \\
2002\end{array}$} & \multirow{2}{*}{$\begin{array}{l}\text { Original } \\
\text { impact }\end{array}$} & \multicolumn{2}{|c|}{ Satellite } & \multirow{2}{*}{$\begin{array}{c}\text { Overflight } \\
(1992-2002)\end{array}$} \\
\hline & & & & & 2001 & 2002 & \\
\hline OSP1 & $54^{\circ} 01.950^{\prime} \mathrm{N}, 02^{\circ} 20.802^{\prime} \mathrm{E}$ & + & & High & 1.849 & 0.417 & 0.374 \\
\hline OSP1b & $54^{\circ} 02.00^{\prime} \mathrm{N}, 02^{\circ} 22.85^{\prime} \mathrm{E}$ & & + & High & 1.675 & 0.318 & 0.406 \\
\hline OSP2 & $54^{\circ} 05.520^{\prime} \mathrm{N}, 02^{\circ} 08.514^{\prime} \mathrm{E}$ & + & + & High & 1.054 & 0.480 & 0.361 \\
\hline OSP3 & $54^{\circ} 02.976^{\prime} \mathrm{N}, 01^{\circ} 59.676^{\prime} \mathrm{E}$ & + & + & Low & 0.715 & 0.385 & 0.239 \\
\hline OSP4 & $53^{\circ} 57.75^{\prime} \mathrm{N}, 02^{\circ} 22.45^{\prime} \mathrm{E}$ & + & & Low & 0.952 & 0.707 & 0.245 \\
\hline OSP5 & $54^{\circ} 02.26^{\prime} \mathrm{N}, 01^{\circ} 55.85^{\prime} \mathrm{E}$ & + & + & Low & 0.578 & 0.469 & 0.159 \\
\hline OSP6 & $54^{\circ} 07.15^{\prime} \mathrm{N}, 02^{\circ} 31.45^{\prime} \mathrm{E}$ & + & + & High & 3.236 & 0.564 & 0.528 \\
\hline OSP7 & $54^{\circ} 00.65^{\prime} \mathrm{N}, 02^{\circ} 05.40^{\prime} \mathrm{E}$ & & + & Low & 1.287 & 0.720 & 0.170 \\
\hline TH1 & $51^{\circ} 31.60^{\prime} \mathrm{N}, 01^{\circ} 44.88^{\prime} \mathrm{E}$ & + & + & High & 0 & 0.112 & 0.286 \\
\hline TH2 & $51^{\circ} 28.47^{\prime} \mathrm{N}, 01^{\circ} 34.69^{\prime} \mathrm{E}$ & + & + & High & 0.154 & 0.157 & 0.214 \\
\hline TH3 & $51^{\circ} 31.941^{\prime} \mathrm{N}, 01^{\circ} 24.935^{\prime} \mathrm{E}$ & + & + & Low & 0.106 & 0.027 & 0.117 \\
\hline TH4 & $51^{\circ} 31.68^{\prime} \mathrm{N}, 01^{\circ} 02.404^{\prime} \mathrm{E}$ & + & + & Low & 0 & 0 & 0.058 \\
\hline TH5 & $51^{\circ} 30.32^{\prime} \mathrm{N}, 01^{\circ} 27.17^{\prime} \mathrm{E}$ & & + & Low & 0.037 & 0.0318 & 0.138 \\
\hline TH6 & $51^{\circ} 33.50^{\prime} \mathrm{N}, 01^{\circ} 27.35^{\prime} \mathrm{E}$ & & + & High & 0.039 & 0.019 & 0.156 \\
\hline
\end{tabular}

The ellipse currents $\left(\mathrm{m} \mathrm{s}^{-1}\right)$ and derived bed-stress $\left(\mathrm{N} \mathrm{m}^{-2}\right)$ are shown in Fig. 2B, $\mathrm{C}$, respectively. Bedstress in the Thames was potentially greater $(>0.6 \mathrm{~N}$ $\mathrm{m}^{-2}$ and up to $\left.1.2 \mathrm{~N} \mathrm{~m}^{-2}\right)$ than in the OSP $\left(<0.4 \mathrm{~N} \mathrm{~m}^{-2}\right)$. Similarly, the ellipse currents in the Thames were bigger and more linear than the rectilinear ellipses in the OSP. With more linear ellipses, the sediment is affected by the tide acting in reverse directions and the velocity of current is zero at high and low tide and maximum in-between.

\section{Sediment characteristics}

The sediments in the Thames comprised $90 \%$ sand $( \pm 7 \%)$ and $9 \%$ silt/clay $( \pm 7 \%)$, whilst those in the OSP had a lower sand $(82 \pm 6 \%)$ and a higher silt/clay (18 \pm $6 \%$ ) content (Table 2), although overall the difference was not significant across the 2 regions. For all sites across the 2 regions the silt content was positively correlated with SPUE $(r=0.8, p<0.01)$, whilst the relationship with sand was negative $(r=-0.8, p<0.01)$
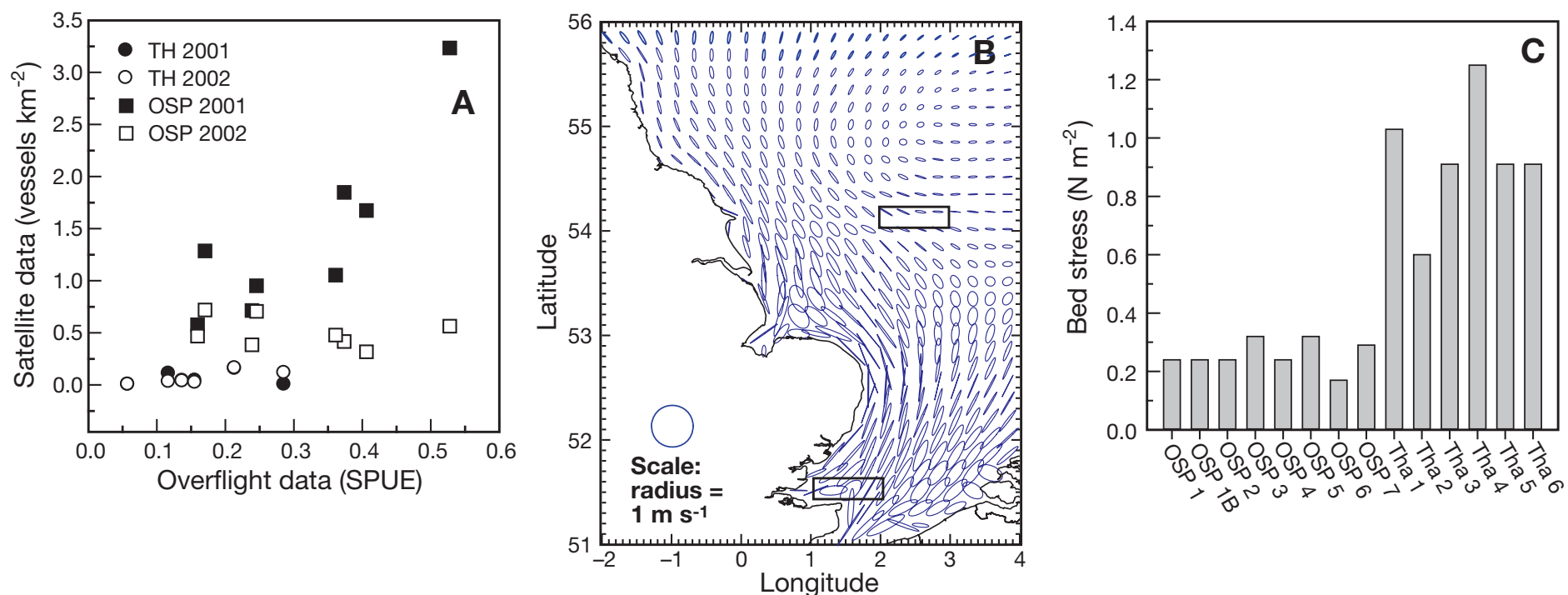

Fig. 2. Trawling impact and the tidal current data used to model bed-stress. (A) Satellite data for 2001 and 2002 plotted against long-term overflight data (1992 to 2002); SPUE: sightings per unit effort. (B) Ellipse currents and direction predicted for mean tides; the radius of scale circle corresponds to a constant speed of $1 \mathrm{~m} \mathrm{~s}^{-1}$; upper and lower rectangles; OSP and Thames regions, respectively. (C) Model output of bed-stress $\left(\mathrm{N} \mathrm{m}^{-2}\right)$ data at each site 
Table 2. Mean sediment ( 0 to $5 \mathrm{~cm}$ ) characteristics of sampling sites in each region of the southern North Sea

\begin{tabular}{|c|c|c|c|c|c|c|}
\hline \multirow[t]{2}{*}{ Site } & \multicolumn{2}{|c|}{ 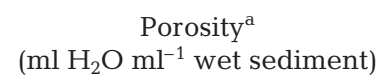 } & \multicolumn{2}{|c|}{$\begin{array}{c}\text { Organic matter }^{\mathrm{b}} \\
\text { (\% dry wt loss on ignition) }\end{array}$} & \multicolumn{2}{|c|}{$\begin{array}{l}\text { Fraction of particles } \\
\text { sand or silt }(\%)^{\mathrm{b}}\end{array}$} \\
\hline & October 2001 & July 2002 & October 2001 & July 2002 & Sand (2000 to $63 \mu \mathrm{m})$ & Silt/clay $(<63 \mu \mathrm{m}$ \\
\hline OSP1 & 0.51 & & 1.21 & & 82.34 & 17.65 \\
\hline OSP1b & & 0.51 & & 1.33 & 80.18 & 19.82 \\
\hline OSP2 & 0.53 & 0.52 & 1.15 & 1.37 & 76.22 & 23.76 \\
\hline OSP3 & 0.51 & 0.54 & 1.09 & 1.54 & 86.18 & 13.59 \\
\hline OSP4 & 0.47 & & 0.80 & & 92.75 & 7.24 \\
\hline OSP5 & & 0.45 & & 1.36 & 84.93 & 14.31 \\
\hline OSP6 & & 0.56 & & 1.46 & 72.97 & 26.99 \\
\hline OSP7 & & 0.52 & & 1.39 & 90.79 & 9.20 \\
\hline TH1 & 0.40 & 0.42 & 0.56 & 0.86 & 82.22 & 14.20 \\
\hline TH2 & 0.46 & 0.51 & 1.27 & 1.78 & 74.40 & 24.48 \\
\hline TH3 & 0.47 & 0.53 & 0.93 & 1.25 & 94.51 & 5.47 \\
\hline TH4 & 0.42 & 0.38 & 0.80 & 0.91 & 97.29 & 2.35 \\
\hline TH5 & & 0.49 & & 1.51 & 88.56 & 11.18 \\
\hline TH6 & & 0.46 & & 0.94 & 95.34 & 4.66 \\
\hline
\end{tabular}

(Fig. 3A). In the Thames, however, the relationship was only evident at the deeper sites and was not significant. In the OSP, the relationship was evenly spread and significant (Fig. 3B). As average sediment grain size can hide sediment features which may control geochemistry, the sediment grain size frequency distributions were examined for both areas (Fig. 3C,D). In the OSP, increased fining and sorting at each site was related to SPUE (roughly from right to left in Fig. 3C). Mainly this was a loss of fine to medium sand and increased sorting of the very fine/fine sand fraction. There was also an increase in the $<63 \mu \mathrm{m}$ fraction (silt). The pattern across the Thames was more variable. Sites TH 1, 2 and 4 included the whole spectrum of trawling activity, but the sediments were far less well sorted (cf. the OSP) and were more variable between replicates, whilst Sites TH 3, 5 and 6 lay mainly in the very fine/fine sand fractions and were much better sorted.

Porosity (Table 2) ranged from 0.45 to 0.56 in the OSP and 0.38 to 0.53 in the Thames, and was on average higher in the OSP (means 0.51 and 0.45 , respectively, $\mathrm{p}<0.001$ ). Poro-

Fig. 3. Sediment grain size analysis. Average fraction of silt and sand particles as a function of SPUE for (A) all sites across both regions and (B) each region separately $(\mathrm{p}=$ significance of the correlation coefficient, r), and sediment grain size frequency distributions for each trawling impact (SPUE) in (C) OSP and (D) Thames (colour shows increasing impact from light blue to black)
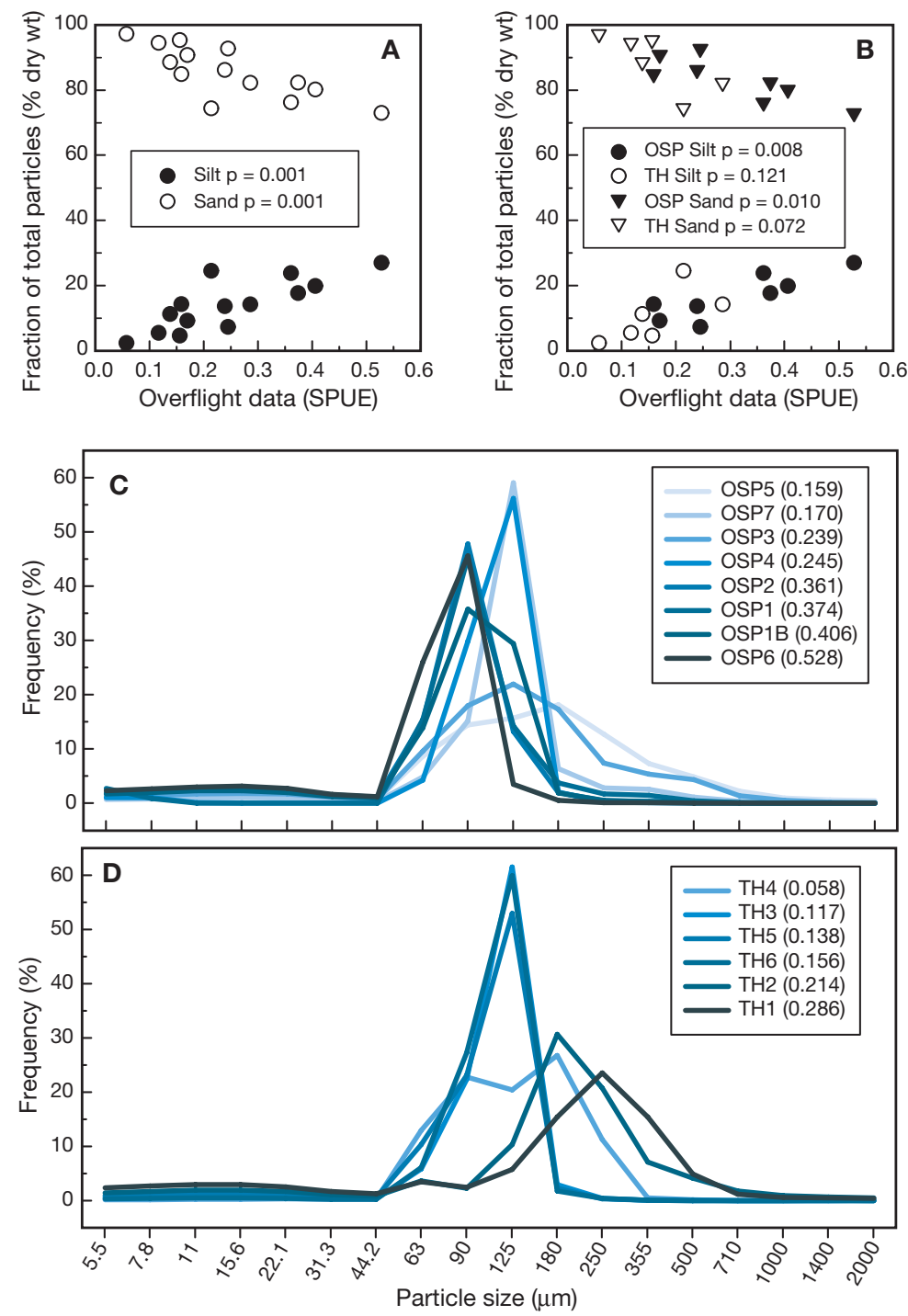
sity was significantly negatively correlated with bedstress in the Thames $(r=-0.727, p=0.017)$ i.e. larger particles were associated with higher tidal energy (Sites TH1 and TH4), and OM (range 0.56 to $1.78 \%$ dry wt) was positively correlated with porosity $(r=0.769$, $\mathrm{p}=0.009$ ). In addition, there was a significant negative correlation between bed-stress and OM $(r=-0.672, \mathrm{p}=$ 0.033) in the Thames. In the OSP, organic matter ranged from 0.80 to 1.54 ( $\%$ dry wt) and was correlated with neither porosity nor bed-stress. The sediments in the OSP were, on average, enriched compared to those in the Thames (1.2 and $1 \%$ dry wt, respectively, $\mathrm{p}=0.027$ ).

\section{Sediment rate measurements}

In October, with the sediments at $14^{\circ} \mathrm{C}$, oxygen uptake was the same (ANOVA) at all sites in the OSP and was, on average, $671 \mu \mathrm{mol} \mathrm{O} \mathrm{m}^{-2} \mathrm{~h}^{-1}$ (SE 51, $\mathrm{n}=4$ ) (Fig. 4A), In the Thames, at $16^{\circ} \mathrm{C}$ (Fig. 4B), oxygen uptake was significantly higher (ANOVA, p < 0.05) at Site TH3, but was comparable among the remaining sites (TH1, 2 and 4): average $584 \mu \mathrm{mol}$ $\mathrm{O}_{2} \mathrm{~m}^{-2} \mathrm{~h}^{-1}(\mathrm{SE} 99, \mathrm{n}=4)$. In July, at $12^{\circ} \mathrm{C}$, oxygen uptake was significantly raised (ANOVA, p < 0.05) at Site OSP1B and OSP2 (2196 and $2381 \mu \mathrm{mol} \mathrm{O} \mathrm{m}^{-2} \mathrm{~h}^{-1}$, respectively) relative to the other OSP sites (average for Site OSP 3, 5, 6, 7: $1317 \mu \mathrm{mol}$ $\left.\mathrm{O}_{2} \mathrm{~m}^{-2} \mathrm{~h}^{-1}, \mathrm{SE} 128, \mathrm{n}=4\right)$. In the Thames, again at $16^{\circ} \mathrm{C}$, oxygen uptake was significantly lower (ANOVA, $p<0.05$ ) at Sites TH1 and TH2 than at the other Thames sites (average for Site TH3, 4, 5, 6: $1829 \mu \mathrm{mol} \mathrm{O} \mathrm{m}^{-2} \mathrm{~h}^{-1}$, SE 55, $\mathrm{n}=4$ ). Overall, oxygen uptake was the same in the OSP and Thames, but the rates measured in July were significantly (ANOVA, $\mathrm{p}<0.05$ ) higher than in October. Simple correlation or multiple linear regression revealed no significant effect of either sediment silt content or trawling impact on oxygen uptake in either region.

In October, sulphate reduction did not differ with depth at any site in the OSP (Fig. 5A), ranging from 0.25 to $1.5 \mathrm{nmol}$ $\mathrm{SO}_{4}{ }^{2-} \mathrm{cm}^{-3} \mathrm{~h}^{-1}$, with only 1 clear peak at $20 \mathrm{~cm}$ (Site OSP2), and the rate (at any one depth) was not significantly different between sites. Patterns in July were similar to those in October in the OSP, but there were peaks at 5 to $6 \mathrm{~cm}$ at Sites
OSP2 and OSP6 (Fig. 5C). In contrast, in the Thames for both October and July, the vertical profiles were more heterogeneous (Fig. 5B,D). In October, activity ranged from 0 to $3.6 \mathrm{nmol} \mathrm{SO}_{4}{ }^{2-} \mathrm{cm}^{-3} \mathrm{~h}^{-1}$, with clear subsurface peaks at 5 to 6 and 5 to $11 \mathrm{~cm}$ at Sites TH2 and TH3, respectively, and in July from 0 to $5.3 \mathrm{nmol} \mathrm{SO}_{4}{ }^{2-} \mathrm{cm}^{-3} \mathrm{~h}^{-1}$ with subsurface peaks at 5 to $6 \mathrm{~cm}$ at Site TH5 and 10 to $11 \mathrm{~cm}$ at Sites TH2 and TH3. As activity did not significantly differ with depth, rates were averaged for each site and then grouped by assigning sites with trawling greater than the median value as 'high' and those below as 'low': median values were 0.3 SPUE for the OSP and 0.15 SPUE for the Thames (Fig. 5E,F). Sulphate reduction was, accordingly, $69 \%$ greater at the high sites
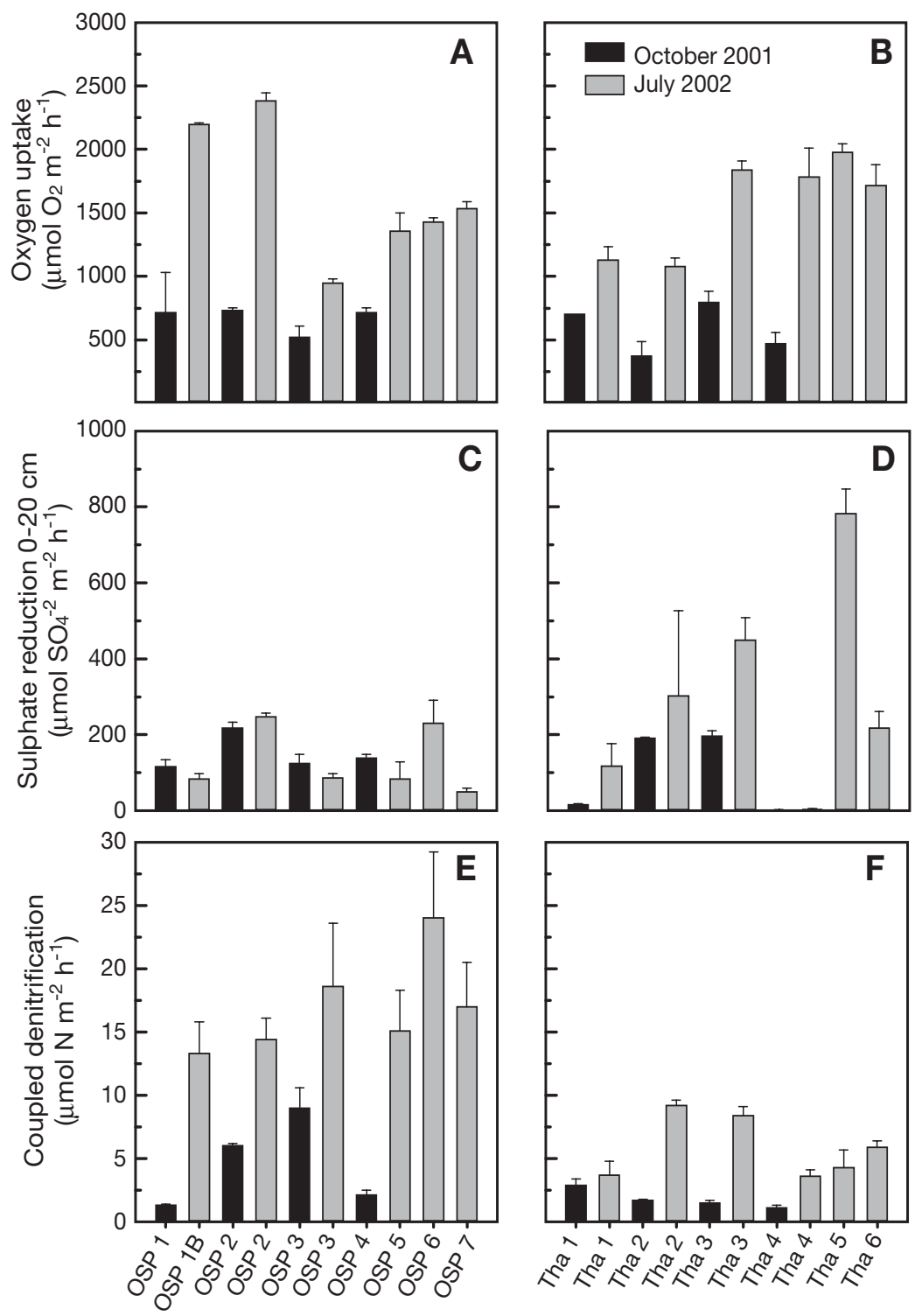

Fig. 4. Mean $+\mathrm{SE}$ biogeochemical process measurements for each site in October 2001 and July 2002 for OSP (A, C, E) and the Thames (B, D, F). n = 3 (except oxygen uptake at Site TH1 in October 2001, where $\mathrm{n}=2$ ) 

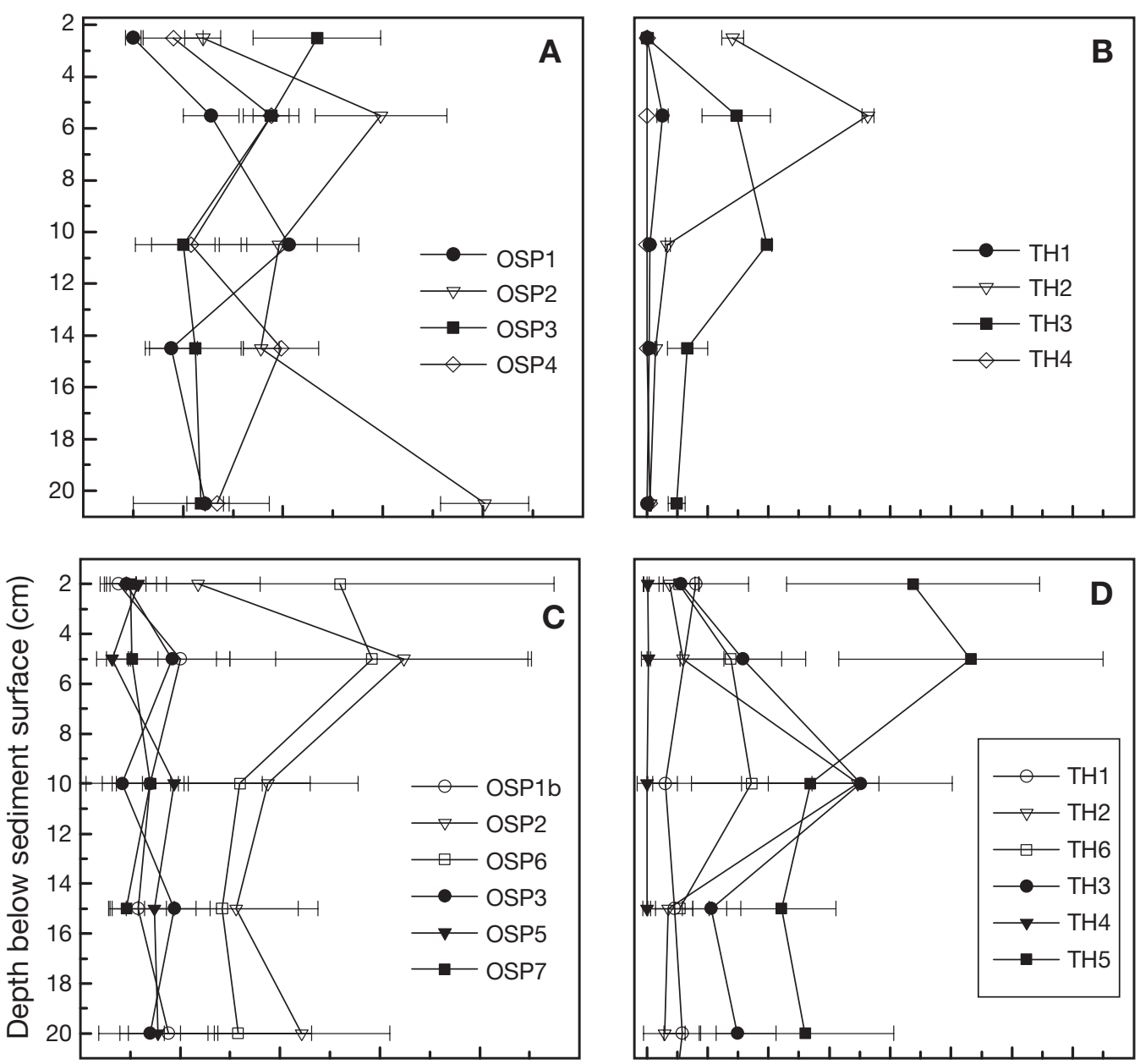

Fig. 5. Depth profiles for sulphate reduction in the OSP (left-hand graphs) and Thames (right-hand graphs) in October 2001 (A, B) and July 2002 (C, D) (means $\pm \mathrm{SE}, \mathrm{n}=3$ ); (E, F) Mean values at each depth (both months combined) and overall mean (lines) for all replicates either side of the median impact $(\mathrm{OSP}=$ 0.3 SPUE, Thames = 0.15 SPUE; see 3rd subsection of 'Results')

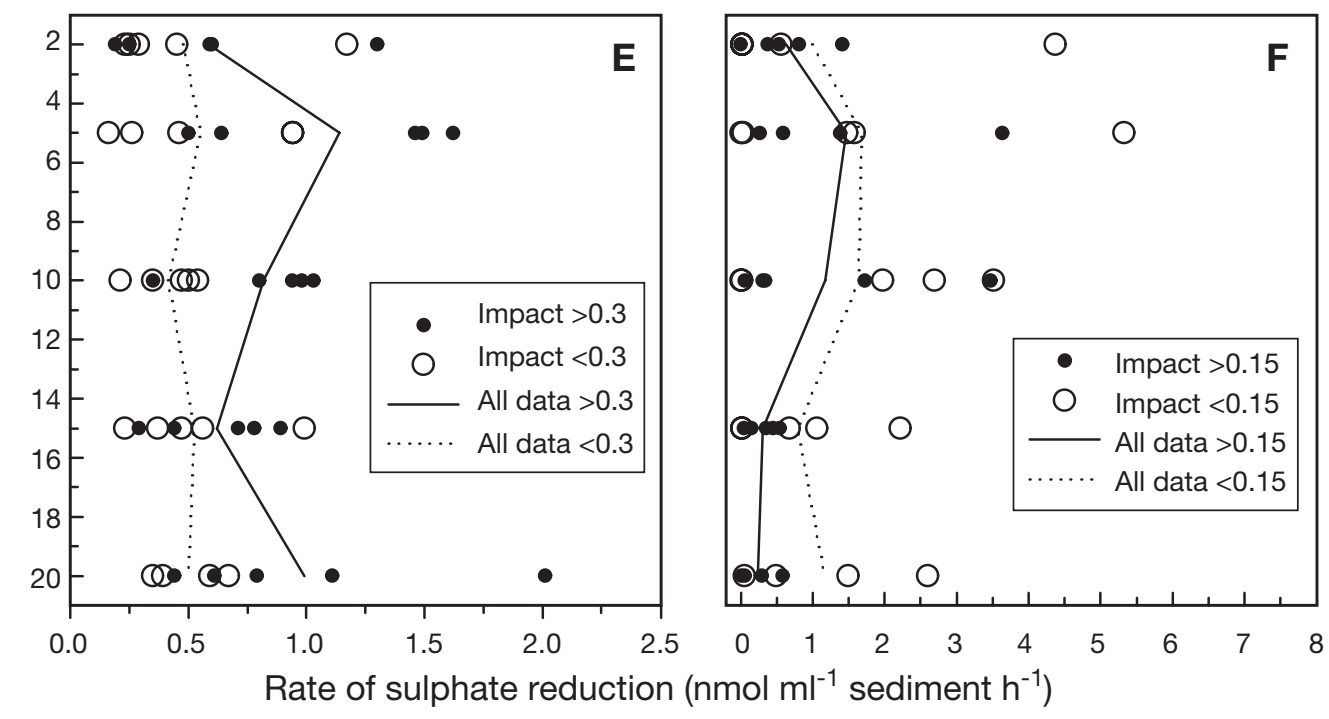

compared to the low sites in the OSP $(0.83 \pm 0.1$ and

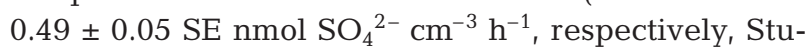
dent's $t$-test, $\mathrm{p}=0.003$ ), but no difference was found in the Thames region $(0.75 \pm 0.2$ and $1.2 \pm 0.3 \mathrm{SE} \mathrm{nmol}$ $\mathrm{SO}_{4}{ }^{2-} \mathrm{cm}^{-3} \mathrm{~h}^{-1}$, respectively).
The sulphate reduction depth profiles were integrated with respect to depth at each site and reported as an areal rate $\left(\mu \mathrm{mol} \mathrm{SO}_{4}{ }^{2-} \mathrm{m}^{-2} \mathrm{~h}^{-1}\right)$. In October 2001,

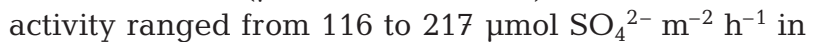
the OSP and from 2 to $196 \mu \mathrm{mol} \mathrm{SO}_{4}{ }^{2-} \mathrm{m}^{-2} \mathrm{~h}^{-1}$ in the 
Thames (Fig. 4C,D). There was no significant difference (ANOVA) across the OSP, but activity at Sites TH2 and TH3 was high relative to that at Sites TH1 and TH4. In July 2002, activity ranged from 49 to $247 \mu \mathrm{mol} \mathrm{SO}_{4}{ }^{2-} \mathrm{m}^{-2} \mathrm{~h}^{-1}$ in the OSP and was significantly elevated at Sites OSP2 and OSP6 (ANOVA, p = 0.002). Activity ranged from 3 to $781 \mu \mathrm{mol} \mathrm{SO}{ }^{2-} \mathrm{m}^{-2}$ $\mathrm{h}^{-1}$ in the Thames. There was a high degree of variance within the data for the Thames, but a nonparametric test (Kruskal-Wallis $H$ ) revealed significant differences between sites $(H=12.37, \mathrm{p}=0.03)$. In the OSP, multiple linear regression revealed a significant positive correlation between sediment silt content, long-term trawling activity and sulphate reduction $(\mathrm{r}=$ 0.751 and 0.66 , respectively; $\mathrm{p}<0.05$; Fig. 6 ). In the model, the effect of silt (as a sediment characteristic clearly linked to trawling and as a proxy for organic matter) was entered first and the subsequent addition of trawling did not significantly improve the fit; hence both were deemed to be influencing sulphate reduction. No such effects were found in the Thames, but the range of $\mathrm{OM}$ content was greater and there was a significant positive correlation between sediment OM content and sulphate reduction $(r=0.709, p=0.022)$.

Denitrification supported by the influx of $\mathrm{NO}_{3}{ }^{-}$from the overlying water $\left(D_{\mathrm{w}}\right)$ was minimal $\left(<1.3 \mu \mathrm{mol} \mathrm{N} \mathrm{m}{ }^{-2}\right.$ $\mathrm{h}^{-1}$ ) at all sites on both occasions (data not shown). In contrast, denitrification coupled to nitrification in the sediment $\left(D_{n}\right)$ ranged from $1 \mu \mathrm{mol} \mathrm{N} \mathrm{m}{ }^{-2} h^{-1}$ at Site TH4 to $24 \mu \mathrm{mol} \mathrm{N} \mathrm{m}{ }^{-2} \mathrm{~h}^{-1}$ at Site OSP6 (Fig. $4 \mathrm{E}, \mathrm{F})$. In October, $\mathrm{D}_{\mathrm{n}}$ was significantly (ANOVA, p < 0.05) higher at Sites OSP2 $\left(6 \mu \mathrm{mol} \mathrm{N} \mathrm{m}{ }^{-2} \mathrm{~h}^{-1}\right)$ and OSP3 $\left(9 \mu \mathrm{mol} \mathrm{N} \mathrm{m}{ }^{-2}\right.$ $\mathrm{h}^{-1}$ ) relative to Sites OSP1 and 4 , but did not vary significantly (ANOVA) across the sites

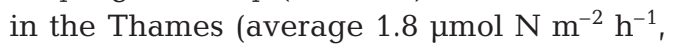
SE 0.4, $\mathrm{n}=4$ ). In July, $\mathrm{D}_{\mathrm{n}}$ was the same across the OSP (average, $17 \mu \mathrm{mol} \mathrm{N} \mathrm{m}{ }^{-2} \mathrm{~h}^{-1}$, SE 1.6, $\mathrm{n}=6$ ) and the Thames (average $6 \mu \mathrm{mol} \mathrm{N} \mathrm{m}{ }^{-2}$ $\mathrm{h}^{-1}, \mathrm{SE} 1, \mathrm{n}=6$ ) except for a significant increase at Sites TH2 and 3. Overall, $\mathrm{D}_{\mathrm{n}}$ was greater in the OSP relative to the Thames in July $(p<0.001)$ but not October. Simple correlation or multiple linear regression revealed no significant effect of either sediment silt content or trawling impact on coupled denitrification in either region. Although the project was not designed to characterise fully anaerobic ammonium oxidation, this contributed 12 and $2 \%$ of the $\mathrm{N}_{2}$ production at Sites OSP1b and TH3, respectively.

The sediments were consistent sources of $\mathrm{NO}_{3}{ }^{-}$to the overlying water at all sites, with little inter- or intra-region variation (ANOVA) and $\mathrm{NO}_{3}^{-}$efflux was on average 12 and
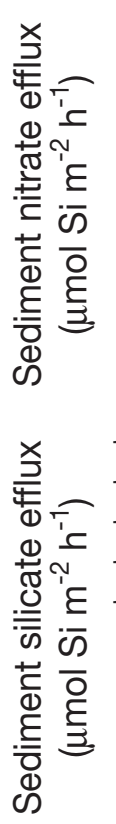

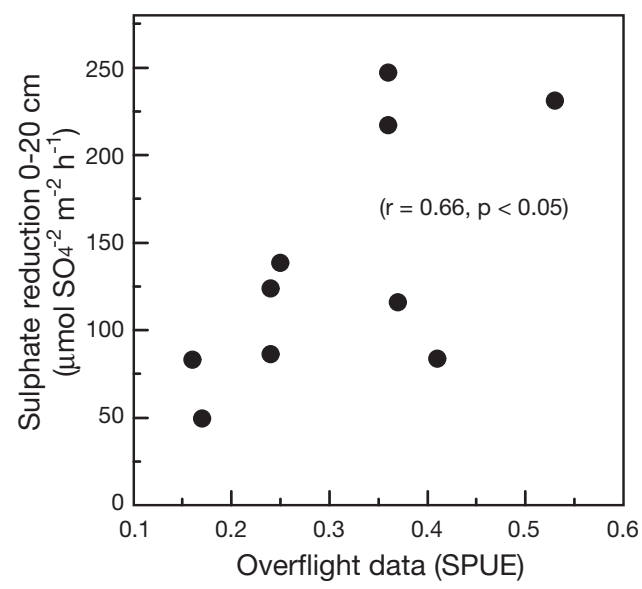

Fig. 6. Scatter-plot of areal rates of sulphate reduction against long-term overflight trawling data (SPUE) for the OSP

$10 \mu \mathrm{mol} \mathrm{NO}{ }^{-} \mathrm{m}^{-2} \mathrm{~h}^{-1}$ for the OSP and Thames, respectively (Fig. 7A,B). In addition, the sediments were strong sources of silicate (Fig. 7C,D) to the overlying water in the OSP, with a median efflux of $88 \mu \mathrm{mol} \mathrm{Si} \mathrm{m}{ }^{-2} \mathrm{~h}^{-1}$ and a range of 38 to $130 \mu \mathrm{mol} \mathrm{Si} \mathrm{m}{ }^{-2} \mathrm{~h}^{-1}$. Silicate efflux was markedly lower across the Thames (except at Site TH5: $92 \mu \mathrm{mol} \mathrm{Si} \mathrm{m}{ }^{-2} \mathrm{~h}^{-1}$ ), with a median efflux of $23 \mu \mathrm{mol}$ $\mathrm{Si} \mathrm{m}{ }^{-2} \mathrm{~h}^{-1}$ and a range of 6 to $40 \mu \mathrm{mol} \mathrm{Si} \mathrm{m}{ }^{-2} \mathrm{~h}^{-1}$. Simple correlation or multiple linear regression revealed no significant effect of either sediment silt content or trawling impact on nutrient exchange in either region.
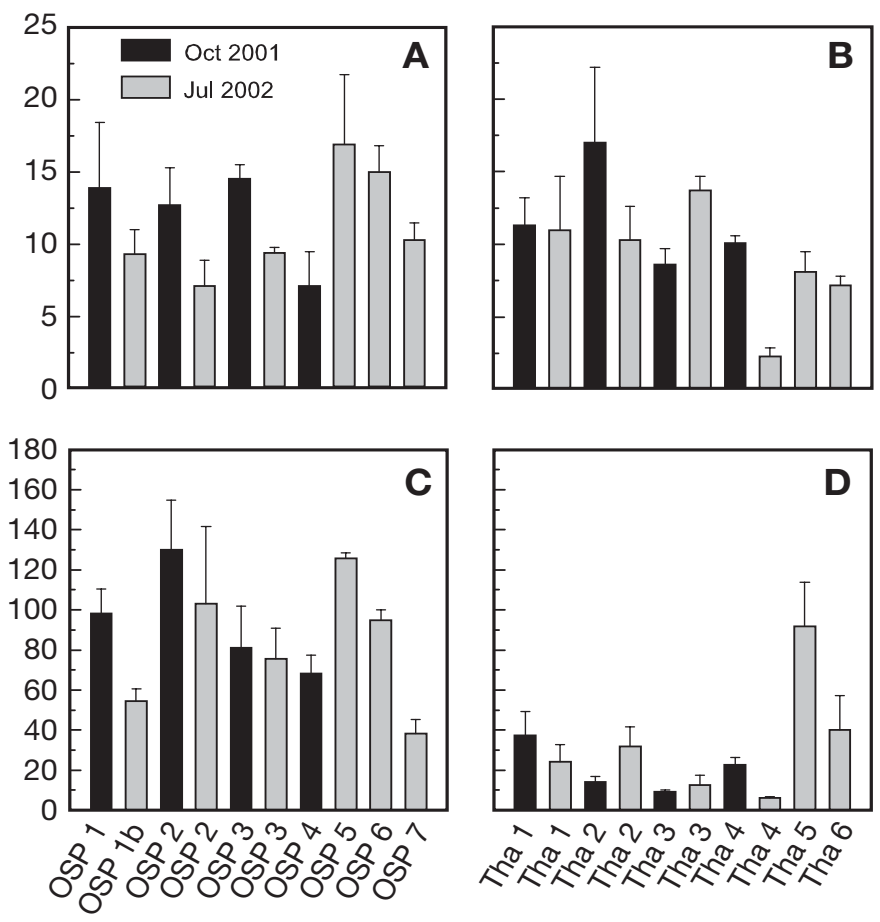

Fig. 7. Mean $+\mathrm{SE}(\mathrm{n}=3)$ sediment-water nutrient exchange in OSP (lefthand graphs) and Thames (right-hand graphs) (A, B) nitrate; (C, D) silicate 


\section{DISCUSSION}

\section{Trawling and natural impacts}

There was significant inter-annual variability in the spatial distribution and magnitude of satellite trawling data between 2001 and 2002. The distribution of trawling effort is affected markedly by management changes, such as temporary closures of specific fishing grounds. In early 2001, for example, an area north-east of the OSP (the 'Cod Box') was closed to the North Sea beam trawl fleet. Dinmore et al. (2003) noted that during this period trawling effort was displaced to the west and potentially towards the OSP. Given this variability in annual satellite data, the overflight data provide a good estimate of long-term impact. This temporal variability in trawling intensity needs to be borne in mind when interpreting possible effects on biogeochemistry.

Ideally we would have compared biogeochemical measurements for trawled and non-trawled sediments with otherwise identical characteristics. Given the ubiquitous nature of trawling in the North Sea, however, this proved impossible. The OM content and porosity of the sediments were essentially the same at all sites in the OSP, and this aided initial site selection. However, an unexpected increase in the sorting of very fine/fine sands, an increase in the silt fraction and the loss of the fine to medium sand fraction with increasing SPUE, became apparent during later data analysis (Fig. 3C). There are 3 hypotheses for the observed shift in sediment grain size distribution in the OSP: (1) The changes were caused by the long-term passage of beam or otter trawls in the OSP. Continual resuspension, in the absence of significant advective transport (Jennings \& Kaiser 1998, P. Krost unpubl.), has led to increased sorting of fine sands and abundance of fines at the sediment surface, i.e. a 'ploughing effect'. (2) The changes are due to the natural progression of sediment through the OSP as a result of historic conditions (i.e. pre-trawling) and extension of present day residual transport and deposition (Proctor et al. 2001). In turn, trawling has focused on these areas where benthic production of food species may well be increased due to the greater deposition of organic detritus. (3) A mixture of Hypotheses 1 and 2, whereby trawling induced changes are overlaid on the natural sedimentary state of the OSP, and natural residual flows can mediate sediment distribution and sorting once trawling resuspension has occurred. There is some evidence that trawling facilitates natural resuspension events directly by changing the erosion threshold, and also indirectly by changing the benthic fauna (Jennings \& Kaiser 1998, Pilskaln et al. 1998, Rowden et al. 1998). Accepting that the OSP is a depo- sitional area for material from the UK east coast (Proctor et al. 2001) and the low possibility of tidal resuspension within the OSP (apart from rare wave driven events), trawling is likely to be the most significant sediment reworking and re-suspension process across the OSP.

In contrast, the Thames is subject to much higher natural disturbance compared to the OSP, and there was a broader range of porosity and $\mathrm{OM}$ in the Thames, both being related to bed-stress, i.e. natural tidal disturbance. In this type of environment, trawling may act as an additional sorting mechanism or disrupt natural sorting in the short-term by ploughing or resuspension. Repeated re-suspension of sediments by trawling coupled to significant tidal currents may lead to removal of fines by advection and an increase in the mean particle size of surface sediments (Mayer et al. 1991), although tidal processes would also produce this effect. Hence, there is no clear relationship between trawling activity and sediment grain size distribution in the Thames (Fig. 3D).

\section{Comparative biogeochemical measurements in the southern North Sea}

The oxygen uptake reported herein for the OSP compares with that in the stratified and transitional waters of the southern North Sea (van Raaphorst et al. 1992, Upton et al. 1993, Osinga et al. 1996: Fig. 1). Oxygen uptake in the Thames compares with previous measurements in this region (Trimmer et al. 2000). Several studies have reported similar rates for the Irish Sea (Trimmer et al. 1999, Gowen et al. 2000). On average, oxygen uptake in July was more than double that in October in both the OSP and Thames (factor 2.4 and 2.7 , respectively). It is not likely that this increase could have been due to differences in temperature, as in both months this was $16^{\circ} \mathrm{C}$ in the Thames, and 12 and $14^{\circ} \mathrm{C}$ in July and October, respectively, in the OSP. Seasonal data $(n=43)$ for the southern North Sea, the mouth of the Thames estuary and upper Great Ouse estuary (Nedwell \& Trimmer 1996, Trimmer et al. 2000) on oxygen uptake and sediment temperature suggest an increase in oxygen uptake of $108 \mu \mathrm{mol} \mathrm{O}_{2} \mathrm{~m}^{-2} \mathrm{~h}^{-1}$ ${ }^{\circ} \mathrm{C}^{-1}\left(\mathrm{r}^{2}=0.41, \mathrm{p}<0.001\right)$, which could not account for the increase measured in the OSP with only a $2{ }^{\circ} \mathrm{C}$ rise in temperature (Trimmer et al. 2003a). Hence the increase was probably due to inputs of pelagic production during the summer (van Raaphorst et al. 1992).

The depth-integrated sulphate reduction at all sites in the OSP (range 49 to $247 \mu \mathrm{mol} \mathrm{SO} \mathrm{SO}_{4}{ }^{2-} \mathrm{m}^{-2} \mathrm{~h}^{-1}$ for October and July) agrees with measurements of Upton et al. (1993) at their Site 6 and Osinga et al. (1996) for the Broad Fourteens and Oyster Grounds (Fig. 1). In 
contrast, there was a broader range of activity across the sites in the Thames ( 2 to $782 \mu \mathrm{mol} \mathrm{SO}{ }_{4}{ }^{2-} \mathrm{m}^{-2} \mathrm{~h}^{-1}$ ) and a greater degree of variance amongst replicated samples. To our knowledge, there are no data for sulphate reduction in the mixed waters of the Thames. Activity at Sites TH2, 3 and 6 agrees with Upton et al.'s (1993) measurement of $370 \mu \mathrm{mol} \mathrm{SO}{ }_{4}{ }^{2-} \mathrm{m}^{-2} \mathrm{~h}^{-1}$. The rate of $782 \mu \mathrm{mol} \mathrm{SO}{ }_{4}{ }^{2-} \mathrm{m}^{-2} \mathrm{~h}^{-1}$ measured at Site TH5 was high, however. The highest and lowest rates were measured in the Thames region, suggesting a great deal of spatial heterogeneity on a comparatively small scale; the range reported herein is comparable with that reported during the entire NERC North Sea Programme (Upton et al. 1993).

The coupled denitrification $\left(D_{n}\right)$ in the OSP and the Thames was of the same magnitude reported for the Oyster Grounds (9 to $13 \mu \mathrm{mol} \mathrm{N} \mathrm{m}{ }^{-2} \mathrm{~h}^{-1}$ (Fig. 1 Site F); the western Irish Sea (4 to $36 \mu \mathrm{mol} \mathrm{N} \mathrm{m}^{-2} \mathrm{~h}^{-1}$ ) and Irish coastal waters $\left(6 \mu \mathrm{mol} \mathrm{N} \mathrm{m}{ }^{-2} \mathrm{~h}^{-1}\right)$ using the same technique (Lohse et al. 1996, Trimmer et al. 1999, 2000). As for sulphate reduction, $D_{n}$ activity varied markedly within any one region and the data available and published suggest a broad range of $D_{n}$ activity in shelf sea sediments, including areas of coarse scoured sand where such activity is not detectable (Trimmer et al. 2000: present Fig. 1, Site A). Although our measurement of anammox was restricted to just 2 sites, the $12 \%$ contribution to $\mathrm{N}_{2}$ production measured in the OSP confirms the presence of this novel reaction in the North Sea and will affect measurement of denitrification using the isotope pairing technique (Nielsen 1992, Risgaard-Petersen et al. 2003).

The sediments in both regions were consistent sources of $\mathrm{NO}_{3}{ }^{-}$and $\mathrm{Si}$ for the overlying water and, overall the rate of efflux agrees with other published rates (van Raaphorst et al. 1992, Nedwell et al. 1993, Lohse et al. 1995). No published $\mathrm{NO}_{3}{ }^{-}$efflux values are available for the Thames, but our measured rates were not significantly different from those measured at the OSP or further north by Nedwell et al. (1993). Very few data exist for Si efflux. Nedwell et al. (1993) (again at their Sites 1 and 6) measured rates of 7 and $43 \mu \mathrm{mol} \mathrm{Si} \mathrm{m}{ }^{-2}$ $\mathrm{h}^{-1}$, respectively, which are at least comparable to our average rates in the Thames and OSP of 29 and $87 \mu \mathrm{mol} \mathrm{Si} \mathrm{m}{ }^{-2} \mathrm{~h}^{-1}$, respectively.

\section{Impact of benthic trawling on biogeochemistry}

The sulphate reduction depth profiles showed similar activity for all sediment depths at all sites in the OSP, but a more mixed structure in the Thames; also, on average, the volume specific rates were $69 \%$ greater at the high impact sites in the OSP, but were equal across high and low sites in the Thames. In addi- tion, the areal rates of sulphate reduction were positively correlated with both silt content (associated with organics [Hansen et al. 1996]) and long-term trawling in the OSP, although no such pattern was visible in the Thames. The shift in sediment grain size seen in the OSP, in terms of increased fines and sorting at sites with higher trawling intensity, could be driven by resuspension or ploughing effects and also by the removal of bioturbating benthic organisms (De Groot \& Lindeboom 1994, Jennings \& Kaiser 1998, Kaiser \& De Groot 2000). The increase in sulphate reduction was correlated with benthic trawling in the OSP (Fig. 6), and supports the idea that a long-term consequence of benthic trawling is the burial of OM associated with fines to deeper sediment strata (Mayer et al. 1991, Trimmer et al. 1999). Also, detritus may accumulate as a result of the removal of macrofauna (Jennings et al. 2001). The fact that there was no relationship with the short-term satellite data suggests that this is an accumulative effect mediated over several years. Typically, sulphate reduction peaks at $\sim 5 \mathrm{~cm}$ and then decreases with increasing depth as organic carbon becomes limiting (Jørgensen 1977, Berner 1985, Nedwell \& Takii 1988, Nedwell 1989). If sulphate reduction were driven by the distribution of organics alone in the OSP, independent of trawling disturbance, then activity should have decayed with depth. Hence, a combination of factors drives the fate of fine particles and associated organics in the OSP, which supports Hypothesis 3 (see first subsection), for particle distribution in the OSP.

Burial of OM may shift the balance between aerobic and anaerobic mineralisation, although the dynamics of organic mineralisation in response to disturbance such as bioturbation are complex (Berner 1985, Mayer et al. 1991, Aller 1994, Hansen et al. 1996, Dauwe et al. 2001). The oxygen uptake data and sulphate reduction data were used to construct an aerobic versus anaerobic carbon mineralisation budget (Table 3). Carbon oxidation via sulphate was simply twice that of oxygen: $2 \mathrm{CH}_{2} \mathrm{O}+\mathrm{SO}_{4}{ }^{2-}=2 \mathrm{CO}_{2}+\mathrm{S}^{2-}+2 \mathrm{H}_{2} \mathrm{O}$ and $\mathrm{CH}_{2} \mathrm{O}+\mathrm{O}_{2}=$ $\mathrm{CO}_{2}+\mathrm{H}_{2} \mathrm{O}$, respectively (further details in Nedwell \& Trimmer 1996), and it was assumed that with a water depth of 20 to $80 \mathrm{~m}, 80 \%$ of the sulphide from sulphate reduction was oxidised at the sediment surface, i.e. an oxygen debit (Jørgensen 1982). In addition, no account was taken of the relatively small amount of oxygen required to drive nitrification. On average, the contribution of sulphate reduction to $\mathrm{C}$ oxidation for the OSP $(26 \%)$ agrees exactly with that measured by Upton et al. (1993) at 6 sites in the North Sea (26\%), i.e. carbon mineralisation is dominated by aerobic respiration in the OSP. Although a significant relationship was found between trawling and sulphate reduction, no significant pattern in the ratio of aerobic to anaerobic mineralisation was measured. This is probably most simply 
Table 3. Mean (SE) mineralisation of organic matter by aerobic respiration and sulphate reduction ( $\mathrm{SO}_{4}{ }^{2-}$ reduc.) in sediments at each site within the 2 regions of the southern North Sea. Oxygen budget has not been debited for nitrification $\left(\mathrm{NO}_{3}{ }^{-}\right.$efflux plus nitrification in sediment, $\mathrm{D}_{\mathrm{n}}$ ). $\mathrm{C}_{\text {oxid. }}$ via $\mathrm{SO}_{4}{ }^{2-}$ reduc.: carbon oxidation via sulphate reduction; $\mathrm{O}_{2}$ upt. $-\mathrm{H}_{2} \mathrm{~S}$ reox.: oxygen uptake minus $\mathrm{H}_{2} \mathrm{~S}$ reoxidation (assuming $80 \%$ of sulphide from sulphate reduction is oxidised at sediment surface at 20 to $200 \mathrm{~m}$ depth: Jørgensen 1982); Total $C_{\text {oxid. }}$ : total oxidation. $\mathrm{n}=3$ (except at Site TH1 in October 2001, where $\mathrm{n}=2$ )

\begin{tabular}{|c|c|c|c|c|c|c|c|c|}
\hline \multirow[t]{2}{*}{ Date, Site } & \multicolumn{5}{|c|}{ Rate process $\left(\mu \mathrm{mol} \mathrm{m} \mathrm{m}^{-2} \mathrm{~h}^{-1}\right)$} & \multicolumn{2}{|c|}{ \% $\mathrm{C}_{\text {oxidation via: }}$} & \multirow{2}{*}{$\mathrm{O}_{2}: \mathrm{SO}_{4}{ }^{2-}$} \\
\hline & $\mathrm{O}_{2}$ uptake & $\mathrm{SO}_{4}{ }^{2-}$ reduc. & $\begin{array}{c}\mathrm{C}_{\text {oxid }} \text { via } \\
\mathrm{SO}_{4}{ }^{2-} \text { reduc. }\end{array}$ & $\begin{array}{c}\mathrm{O}_{2} \text { upt. - } \\
\mathrm{H}_{2} \mathrm{~S} \text { reox. }\end{array}$ & $\begin{array}{c}\text { Total C } \\
\text { oxid. }\end{array}$ & $\mathrm{O}_{2}$ & $\mathrm{SO}_{4}{ }^{2-}$ & \\
\hline Oct OSP1 & $716(316)$ & $116(18)$ & 232 & 531 & 762 & 70 & 30 & 6 \\
\hline Oct OSP2 & $734(20)$ & $217(16)$ & 434 & 387 & 821 & 47 & 53 & 3 \\
\hline Oct OSP3 & $520(88)$ & $124(25)$ & 248 & 322 & 570 & 57 & 43 & 4 \\
\hline Oct OSP4 & $715(40)$ & $138(10)$ & 277 & 494 & 770 & 64 & 36 & 5 \\
\hline July OSP1b & $2196(12)$ & $84(15)$ & 167 & 2045 & 2213 & 92 & 8 & 26 \\
\hline July OSP2 & 2381 (67) & 247 (10) & 494 & 1986 & 2480 & 80 & 20 & 10 \\
\hline July OSP6 & $1429(32)$ & 231 (59) & 462 & 1059 & 1521 & 70 & 30 & 6 \\
\hline July OSP3 & $948(32)$ & 86 (12) & 172 & 810 & 982 & 82 & 18 & 11 \\
\hline July OSP5 & $1357(142)$ & $83(45)$ & 166 & 1224 & 1390 & 88 & 12 & 16 \\
\hline July OSP7 & $1535(52)$ & 49 (10) & 99 & 1456 & 1555 & 94 & 6 & 31 \\
\hline Oct TH1 & 701 & $15(4)$ & 30 & 677 & 707 & 96 & 4 & 46 \\
\hline Oct TH2 & $371(114)$ & $190(3)$ & 381 & 66 & 447 & 15 & 85 & 2 \\
\hline Oct TH3 & 796 (89) & $196(14)$ & 392 & 482 & 874 & 55 & 45 & 4 \\
\hline Oct TH4 & $470(88)$ & $2(1)$ & 5 & 466 & 471 & 99 & 1 & 198 \\
\hline July TH1 & 1128 (108) & $118(59)$ & 236 & 939 & 1175 & 80 & 20 & 10 \\
\hline July TH2 & $1076(67)$ & $302(225)$ & 605 & 592 & 1197 & 49 & 51 & 4 \\
\hline July TH6 & 1717 (165) & $218(44)$ & 436 & 1368 & 1804 & $\begin{array}{l}49 \\
76\end{array}$ & 24 & $\begin{array}{l}4 \\
8\end{array}$ \\
\hline July TH3 & $1838(72)$ & 448 (59) & 897 & 1121 & 2017 & 56 & 44 & 4 \\
\hline July TH4 & $1784(227)$ & $3(2)$ & 6 & 1780 & 1785 & 100 & 0 & 646 \\
\hline July TH5 & $1977(67)$ & $782(66)$ & 1563 & 726 & 2290 & 32 & 68 & 3 \\
\hline
\end{tabular}

explained by the relatively large magnitude of oxygen uptake $(74 \%)$ compared to sulphate reduction $(26 \%)$. Whether a shift from aerobic to anaerobic mineralisation affects the net rate of mineralisation will depend on the nature of the organic detritus and the frequency of disturbance, but a larger fraction of organic detritus may become permanently buried in the OSP (Hansen \& Blackburn 1991, Aller 1994, Kristensen et al. 1995). Our measurements of OM via loss on ignition were too crude to reveal any differences between sites within the OSP, and the actual dynamics of trawling impact, nature of $\mathrm{C}$ buried and stimulation of sulphate reduction need fully quantifying.

Trawling activity will, in theory, resuspend and reoxidise the top 5 to $6 \mathrm{~cm}$ of sediment and suppress sulphate reduction in the short-term. Osinga et al. (1996) suggested that such a mechanism prevented sulphate reduction becoming established until 5 to $10 \mathrm{~cm}$ depth in the Broad Fourteens. Given that sulphate reduction remained essentially constant with depth and that the rates were raised at the high trawling impact sites in the OSP, then whilst trawling activity redistributes OM to depth, its effect on sediment redox cannot be so important as tidal disturbance, e.g. in the Broad Fourteens. Otherwise, inhibition at the surface and measurable stimulation with depth would be expected.

The sulphate reduction depth profiles in the Thames were heterogeneous, with peaks of activity at $10 \mathrm{~cm}$ for both high and low impact trawling sites (Fig. 5B,D). All the sites in the Thames are subject to bed-stress in excess of $0.6 \mathrm{~N} \mathrm{~m}^{-2}$ (Fig. 2C) and, as argued by Osinga et al. (1996) for the Broad Fourteens, this could resuspend sediment and suppress sulphate reduction in the upper $5 \mathrm{~cm}$. As there was no relationship between benthic trawling and sulphate reduction in the Thames (as there was in the OSP), bed-stress in excess of $0.6 \mathrm{~N} \mathrm{~m}^{-2}$ probably masks any impact of trawling. This could be related to the OM of the sediments, at a coarse scale, as there was a negative correlation between OM and bedstress and, in turn, a positive correlation between sulphate reduction and OM in the Thames, but not in the OSP. The depth profiles for Sites TH1 and (especially) TH4 (where bed-stress potentially exceeded $1 \mathrm{~N}$ $\mathrm{m}^{-2}$ ) had very low activity to depths of 15 to $25 \mathrm{~cm}$. This low activity was probably due to a combination of continual re-suspension of the upper strata and current derived irrigation with oxic water (Thibodeaux \& Boyle 1987, Huettel \& Gust 1992a,b).

Measurement of the impact of trawling on sedimentwater nutrient exchange has not always been conclusive (Riemann \& Hoffmann 1991, Warnken et al. 2003). Our measurements of $\mathrm{NO}_{3}{ }^{-}$and $\mathrm{Si}$ efflux suggest that there is no long-term measurable effect of trawling on the exchange of $\mathrm{NO}_{3}{ }^{-}$and $\mathrm{Si}$. Whilst nutrients accumulate to high concentrations at depth, their fate (e.g. nitrification of mineralised $\mathrm{NH}_{4}^{+}$) at the sediment- 
water interface will be governed by the characteristics of the top few millimetres of sediment. In addition, no relationship could be found between trawling and pore water concentrations or the gradient of concentration with depth (data not shown). Falcão et al. (2003) demonstrated that pre-trawl conditions for pore water nutrient regimes were rapidly re-established following an impact. Hence, despite the sustained trawling in our 2 regions the long-term efflux of nutrients remained unaffected.

There was also no measurable effect of trawling on coupled denitrification. The only significant differences were recorded between single sites in the OSP or the Thames. Hence, natural variation within a region was as significant as any impact of trawling activity. Burrow formation and irrigation by macrofauna is known to stimulate denitrification and, as trawling reduces the density of macrofauna in areas such as the OSP, a suppression of denitrification might have been expected at high trawling intensities (Rysgaard et al. 1995, Jennings et al. 2001). However, Jennings et al. (2002) showed that the small infauna community (largely polycheates) is unaffected by trawling activity and, hence, if densities of the small polycheates are great enough their burrowing activities could continue to stimulate coupled denitrification $\left(D_{n}\right)$ and overall nutrient exchange. Denitrification occurs in a narrow suboxic band immediately beneath the oxic layer (Christensen et al. 1989), and the data suggest that the oxic and suboxic layers are rapidly reestablished following trawling disturbance. Although we could not evaluate $\mathrm{NH}_{4}{ }^{+}$exchange, it is often minimal in shelf sediments (Trimmer et al. 1999). Therefore, the sum of $\mathrm{NO}_{3}{ }^{-}$exchange and $\mathrm{D}_{\mathrm{n}}$ gives not only a measure of gross nitrification but also of gross $\mathrm{N}$ mineralisation. In turn, the pattern of both $\mathrm{NO}_{3}{ }^{-}$exchange and $\mathrm{D}_{\mathrm{n}}$ across the trawling gradient suggests that the $\mathrm{N}$ mineralisation budget remains largely unaffected.

The re-establishment of the oxic and suboxic layers following trawling disturbance was further supported by the oxygen uptake data. The stimulation of sulphate reduction in the OSP might have been expected to increase oxygen uptake indirectly via the re-oxidation of sulphides at the oxic/anoxic interface. The maximum stimulation of sulphate reduction across the

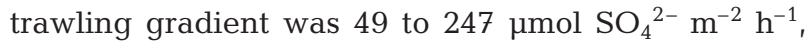
which could potentially increase oxygen uptake from 98 to $494 \mu \mathrm{mol} \mathrm{O} \mathrm{m}^{-2} \mathrm{~h}^{-1}$. It would, however, be difficult to measure an effect of this magnitude against the background of oxygen uptake. This does not discount the periodical remobilising of reduced compounds into the overlying water and increasing oxygen consumption through trawling activity (Riemann \& Hoffmann 1991). Periodic resuspension of the surface sediment would break the coupling between sulphides and oxy- gen uptake by the sediment in situ, which would not be detected at the actual time of measurement. It is clear that benthic trawling causes mortality of benthic fauna (Jennings et al. 2001), and Osinga et al. (1996) speculated that the decay of these animals stimulates oxygen uptake in the Oyster Grounds in the winter. Our measurements were restricted to the summer and autumn, and as trawling activity tends to be more intense during the winter, such short-term stimulation cannot be ruled out. However, our data suggest that there is no long-term impact from benthic trawling on either oxic or suboxic biogeochemical processes.

The density of benthic trawling operating in the southern North Sea in 2002 is illustrated in Fig. 1. Accepting some of the limitations in estimating trawling intensity, clearly, a very large part of the transitional and stratified region is subject to intensive trawling activity. Our data suggest that biogeochemical processes in the upper layers of sediment, oxic and suboxic, are unaffected by trawling in the long-term. However, in deeper anoxic sediment, mineralisation via sulphate reduction may be stimulated by the extra disturbance, at least in areas where tidal energy is slight.

Acknowledgements. This work was part of the AE1224 programme carried out by CEFAS funded by DEFRA. The views expressed are those of the authors and do not reflect the policies of the funding departments. Fishing vessel activity surveillance data were provided by DEFRA in raw, uninterpreted form, and DEFRA does not accept any liability whatsoever for any subsequent interpretation. The authors wish to thank the Captain, officers and crew of the RV 'Corystes' and S. Jennings and P. Larcombe for comments on the text and help with sediment data.

\section{LITERATURE CITED}

Aller RC (1988) Benthic fauna and biogeochemical processes in marine sediments: the role of burrow structures. In: Blackburn TH, Sørensen J (eds) Nitrogen cycling in coastal marine environments. John Wiley \& Sons, London, p 301-340

Aller RC (1994) Bioturbation and remineralisation of sedimentary organic matter: effects of redox oscillation. Chem Geol 114:331-345

Berner RA (1985) Sulphate reduction, organic matter decomposition and pyrite formation. Philos Trans R Soc Lond A 315:25-38

Blackburn TH (1997) Release of nitrogen compounds following resuspension of sediment: model predictions. J Mar Syst 11:343-352

Blumberg AF, Mellor GL (1987) A description of a 3-dimensional coastal ocean circulation model. In: Heaps NS (ed) Three dimensional coastal ocean models. Coastal and Estuarine Sciences 4. American Geophysical Union, Washington, p 1-16

Callaway R, Alsvåg J, de Boois I, Cotter J and 8 others (2002) Diversity and community structure of epibenthic invertebrates and fish in the North Sea. ICES J Mar Sci 59: $1199-1214$ 
Christensen PB, Nielsen LP, Revsbech NP, Sørensen J (1989) Microzonation of denitrification activity in stream sediments as studied with a combined oxygen and nitrous oxide microsensor. Appl Environ Microbiol 55:1234-1241

Churchill JH (1989) The effect of commercial trawling on sediment resuspension and transport over the Middle Atlantic Bight continental shelf. Cont Shelf Res 9:841-864

Dauwe B, Middelburg JJ, Herman PMJ (2001) Effect of oxygen on the degradability of organic matter in subtidal and intertidal sediments of the North Sea area. Mar Ecol Prog Ser 215:13-22

De Groot SJ, Lindeboom HJ (1994) Environmental impact of bottom gears on benthic fauna in relation to natural resources management and protection of the North Sea. NIOZ-Rapport 1994-11, RIVO-DLO report CO26/94 Netherlands Institute for Sea Research, Den Burg, Texel

Dinmore TA, Duplisea DE, Rackham BD, Maxwell DL, Jennings $S$ (2003) Impact of a large-scale area closure on patterns of fishing disturbance and the consequences for benthic communities. ICES J Mar Sci 60:371-380

Falcão M, Gaspar MB, Caetano M, Santos MN, Vale C (2003) Short-term environmental impact of clam dredging in coastal waters (south of Portugal): chemical disturbance and subsequent recovery of seabed. Mar Environ Res 56: 649-664

Fanning KA, Carder KL, Betzer PR (1982) Sediment resuspension by coastal waters: a potential mechanism for nutrient recycling on the ocean's margins. Deep Sea Res 29(8A): 953-965

Fossing H, Jørgensen BB (1989) Measurement of bacterial sulphate reduction in sediments: evaluation of a singlestep chromium reduction method. Biogeochemistry 8: 205-222

Gowen RJ, Mills DK, Trimmer M, Nedwell DB (2000) Production and its fate in 2 coastal regions of the Irish Sea: the influence of anthropogenic nutrients. Mar Ecol Prog Ser 208:51-64

Hansen K, King GM, Kristensen E (1996) Impact of the shoftshell clam Mya arenaria on sulphate reduction in an intertidal sediment. Aquat Microb Ecol 10:181-194

Hansen LS, Blackburn TH (1991) Aerobic and anaerobic mineralisation of organic material in marine sediment microcosms. Mar Ecol Prog Ser 75:283-291

Henriksen K, Rasmussen MB, Jensen A (1983) Effect of bioturbation on microbial nitrogen transformations in the sediment and fluxes of ammonium and nitrate to the overlying water. Environ Biogeochem 35:193-205

Huettel M, Gust G (1992a) Solute release mechanism from confined sediment cores and stirred benthic chambers and flume flows. Mar Ecol Prog Ser 82:187-197

Huettel M, Gust G (1992b) Impact of bioroughness on interfacial solute exchange in permeable sediments. Mar Ecol Prog Ser 89:253-267

Jennings S, Kaiser MJ (1998) The effects of fishing on marine ecosystems. Adv Mar Biol 34:203-352

Jennings S, Alvsvå J, Cotter AJ, Ehrich S and 5 others (1999) Fishing effects in northeast Atlantic shelf seas: patterns in fishing effort, diversity and community structure. III. International fishing effort in the North Sea: an analysis of temporal and spatial trends. Fish Res 40:125-134

Jennings S, Dinmore TA, Duplisea DE, Warr KJ, Lancaster JE (2001) Trawling disturbance can modify benthic production processes. J Anim Ecol 70:459-475

Jennings S, Nicholson MD, Dinmore TA, Lancaster JE (2002) Effects of chronic trawling disturbance on the production of infaunal communities. Mar Ecol Prog Ser 243:251-260

Jørgensen BB (1977) The sulphur cycle of a coastal marine sediment (Limfjorden, Denmark). Limnol Oceanogr 22: 814-832

Jørgensen BB (1982) Mineralization of organic matter in the sea bed - the role of sulphate reduction. Nature 296:643-645

Jørgensen BB (1983) Processes at the sediment-water interface. In: Bolin B, Cook RB (eds) The major biogeochemical cycles and their interactions. SCOPE Report No. 21. Wiley, New York, p 477-509

Kaiser MJ, De Groot SJ (2000) The effects of fishing on nontarget species and habitats: biological, conservation and socio-economic issues. Blackwell Science, Oxford

Kirkwood DS (1996) Nutrients: practical notes on their determination in seawater. ICES Tech Mar Environ Sci 17

Kristensen E (2000) Organic matter diagenesis at the oxic/ anoxic interface in coastal marine sediments, with emphasis on the role of burrowing animals. Hydrobiologia 426: $1-24$

Kristensen E, Ahmed SI, Devol AH (1995) Aerobic and anaerobic decomposition of organic matter: which is fastest? Limnol Oceangr 40:1470-1437

Lohse L, Malschaert HFP, Slomp CP, Helder W, van Raaphorst W (1995) Sediment-water fluxes of inorganic nitrogen compounds along the transport route of organic matter in the North Sea. Ophelia 41:173-197

Lohse L, Kloosterhuis HT, van Raaphorst W, Helder W (1996) Denitrification rates as measured by the isotope pairing method and by the acetylene inhibition technique in continental shelf sediments of the North Sea. Mar Ecol Prog Ser 132:169-179

Mayer LM, Schick DF, Findlay RH, Rice DL (1991) Effects of commercial dragging on sedimentary organic matter. Mar Environ Res 31:249-261

Nedwell DB (1989) Benthic microbial activity in an Antarctic coastal sediment at Signy Island, South Orkney Islands. Estuar Coast Shelf Sci 28:507-516

Nedwell DB, Takii S (1988) Bacterial sulphate reduction in sediments of a European saltmarsh: acid-volatile and tinreducible products. Estuar Coast Shelf Sci 26:599-606

Nedwell DB, Trimmer M (1996) Nitrogen fluxes through the upper estuary of the Great Ouse, England: the role of the bottom sediments. Mar Ecol Prog Ser 142:273-286

Nedwell DB, Parkes RJ, Upton AC, Assinder DJ (1993) Seasonal fluxes across the sediment-water interface, and process within sediments. Philos Trans R Soc Lond A 343: $519-529$

Nielsen LP (1992) Denitrification in sediment determined from nitrogen isotope pairing. FEMS Microbiol Ecol 86:357-362

Osinga R, Kop AJ, Duineveld GCA, Prins RA, van Duyl FC (1996) Benthic mineralisation rates at 2 locations in the southern North Sea. J Sea Res 36:181-191

Palanques A, Guillen J, Puig P (2001) Impact of bottom trawling on water turbidity and muddy sediment of an unfished continental shelf. Limnol Oceanogr 46:1100-1110

Pelegri SP, Nielson LP, Blackburn TH (1994) Denitrification in estuarine sediment stimulated by the irrigation activity of the amphipod Corophium volutator. Mar Ecol Prog Ser 105:285-90

Pilskaln CH, Churchill JH, Mayer LM (1998) Resuspension of sediment by bottom trawling in the Gulf of Maine and potential geochemical consequences. Conserv Biol 12: 1223-1229

Proctor R, Holt JT, Balson P (2001) Sediment deposition in offshore deeps of the Western North Sea: questions for models. Estuar Coast Shelf Sci 53:553-567

Riemann B, Hoffmann E (1991) Ecological consequences of dredging and bottom trawling in the Limfjord, Denmark. Mar Ecol Prog Ser 69:171-178 
Rijnsdorp AD, Bujiis AM, Storbeck F, Visser E (1998) Microscale distribution of beam trawl effort in the southern North Sea between 1993 and 1996 in relation to the trawling frequency of the sea bed and the distribution of benthic organisms. ICES J Mar Sci 55:403-419

Risgaard-Petersen N, Nielsen LP, Rysgaard S, Dalsgaard T, Louise Meyer R (2003) Application of the isotope pairing technique in sediments where anammox and denitrification coexist. Limnol Oceanogr Methods 1:63-73

Rowden AA, Jago CF, Jones SE (1998) Influence of benthic macrofauna on the geotechnical and geophysical properties of surficial sediment, North Sea. Cont Shelf Res 18: $1347-1363$

Rysgaard S, Risgaard-Petersen N, Sloth NP, Jensen K, Nielsen LP (1994) Oxygen regulation of nitrification and denitrification in sediments. Limnol Oceanogr 39: 1643-1652

Rysgaard S, Christensen PB, Nielsen LP (1995) Seasonal variation in nitrification and denitrification in estuarine sediment colonised by benthic microalgae and bioturbating infauna. Mar Ecol Prog Ser 126:111-121

Silverman BW (1986) Density estimation for statistics and data analysis. Chapman \& Hall, London

Sorokin YL (1962) Experimental investigation of bacterial sulphate reduction in the Black Sea using ${ }^{35} \mathrm{~S}$. Mikrobiologiya 31:402-410

Thamdrup B, Dalsgaard T (2002) Production of $\mathrm{N}_{2}$ through anaerobic ammonium oxidation coupled to nitrate reduction in marine sediments. Appl Environ Microbiol 68: $1312-1318$

Thibodeaux LJ, Boyle JD (1987) Bedform-generated convective transport in bottom sediment. Nature 325:341-343

Trimmer M, Gowen RJ, Stewart BM, Nedwell DB (1999) The spring bloom and its impact on benthic mineralisation

Editorial responsibility: Otto Kinne (Editor-in-Chief), Oldendorf/Luhe, Germany rates in western Irish Sea sediments. Mar Ecol Prog Ser 185:37-46

Trimmer M, Nedwell DB, Sivyer DB, Malcolm SJ (2000) Seasonal benthic organic matter mineralisation measured by oxygen uptake and denitrification along a transect of the inner and outer River Thames estuary, UK. Mar Ecol Prog Ser 197:103-119

Trimmer M, Gowen RJ, Stewart BM (2003a) Changes in sediment processes across the western Irish Sea front. Estuar Coast Shelf Sci 56:1011-1019

Trimmer M, Nicholls JC, Deflandre B (2003b) Anaerobic ammonium oxidation measured in sediments along the Thames estuary, UK. Appl Environ Microbiol 69:6447-6454

Upton AC, Nedwell DB, Parkes RJ, Harvey SM (1993) Seasonal benthic microbial activity in the southern North Sea; oxygen uptake and sulphate reduction. Mar Ecol Prog Ser 101:273-281

van Raaphorst W, Kloosterhuis HT, Berghuis EM, Gieles AJM, Malschaert JFP, van Noort GJ (1992) Nitrogen cycling in 2 types of sediments of the southern North Sea (Frisian Front, Broad Fourteens): field data and mesocosm results. Neth J Sea Res 28:293-316

Warnken KW, Gill GA, Dellapenna TM, Lehman RD, Harper DE, Allison MA (2003) The effects of shrimp trawling on sediment oxygen consumption and the fluxes of trace metals and nutrients from estuarine sediments. Estuar Coast Shelf Sci 57:25-42

Watling L, Norse EA (1998) Disturbance of the seabed by mobile fishing gear: a comparison to forest clear-cutting. Conserv Biol 12:1180-1197

Watling L, Findlay RH, Mayer LM, Schick DF (2001) Impact of scallop drag on the sediment chemistry, microbiota, and faunal assemblages of a shallow subtidal marine benthic community. J Sea Res 46:309-324

Submitted: September 28, 2004; Accepted: March 8, 2005 Proofs received from author(s): July 25, 2005 